\title{
VIVIR COMO CRISTIANOS Y PAGAR COMO MOROS. GENEALOGÍA MEDIEVAL DE LA SERVIDUMBRE MORISCA EN EL REINO DE VALENCIA
}

\author{
JOSEP TORRÓ \\ Universitat de València
}

Fecha de recepción: diciembre 2008

Fecha de aceptación: marzo 2009

Las disposiciones del año 1525 dirigidas a la conversión general de los musulmanes del reino de Valencia no sólo encendieron diversas revueltas locales, en particular la de la Sierra de Espadán, sino que también tuvieron como efecto una serie de negociaciones llevadas a cabo por representantes de las aljamas y morerías del país ante el emperador Carlos. Los acuerdos a los que se llegó, aprobados definitivamente en las cortes de Monzón de 1528, se recuerdan, sobre todo, por las moratorias concedidas a los nuevos convertidos en orden a abandonar su lengua, indumentaria y costumbres, y muy especialmente por el hecho de suspenderse, durante cuarenta años, la persecución inquisitorial de los ritos del islam. Ahora bien, entre las peticiones de los doce síndicos enviados por las aljamas, merece destacarse la que solicitaba la igualación de cristianos nuevos y cristianos viejos en materia de servidumbres, tributos y movilidad. Vale la pena reproducir el capítulo íntegramente:

«Ítem por quanto es cierto que los moros del reyno, por ser sostenidos como moros, eran contentos de sufrir muchas servidumbres y açofrar y pagar muchos pechos a su Magestad, los que eran sus vasallos immediatos a sus señores, los quales no es razón que oy los paguen siendo christianos, ni los podían pagar no pudiendo trabajar en los días de fiesta mandados por la Iglesia christiana; ni es razón que sean forçados d'estar en los lugares a donde oy están, antes bien que tengan libertad de mudar sus domicilios de un lugar de señorío a otro, o en el realengo, como tienen los christianos, y que en esto sean bien favorecidos por officiales de su Magestad. Suplican por ende que por su C(athólica) Magestad sean igualados en pagar los pechos y servidumbres y otras rentas como los christianos viejos, cada uno con su lugar, así que no sean apremiados de pagar más ni menos que los christianos, y en los lugares donde no uviere christianos sea reglado como en los lugares de 
christianos más çerca... y que siempre que algún nuevo convertido quisiere mudar domicilio lo pueda libremente haçer como otro christiano del dicho reyno» ${ }^{1}$.

La obviedad de las implicaciones contenidas en la demanda de los nuevos convertidos no excusa su consideración. Lo que el texto pone de manifiesto es, ante todo, la existencia de una nítida diferenciación de estatus entre cristianos y musulmanes en el reino de Valencia. También se hace patente que el mantenimiento del carácter subalterno del cuerpo social musulmán, supuestamente convertido, constituye un obstáculo radical a cualquier proceso de asimilación efectiva que se pretenda promover. Pero además, el capítulo enuncia con precisión tres aspectos decisivos de dicha inferioridad de estatus. Primero: pagan más rentas («pechos») que los cristianos, tanto al rey como a los otros señores. Segundo: se hallan sujetos a obligaciones de carácter servil («servidumbres» y «çofras») que no se aplican, o al menos no con la misma intensidad, a los cristianos. Tercero: su movilidad geográfica se halla sujeta a restricciones («forçados d'estar en los lugares») que les impiden «mudar domicilio» con el grado de libertad deseado, por decirlo con la más suave de las interpretaciones posibles.

Aunque el emperador pareció acoger la demanda con una actitud favorable («Plaze a su Magestad que así mesmo en esto sean tratados como christianos»), lo cierto es que suspendió de forma indefinida cualquier decisión al respecto, supuestamente a la espera de reunir información suficiente para evitar «agravio de partes» y «proveer conforme a justicia». Evidentemente se trataba de una cuestión de gran calado. Acceder a tales peticiones hubiera tenido unas consecuencias de magnitudes casi equiparables a las que alcanzaría, posteriormente, la expulsión general en cuanto a perjuicio de los señores de moriscos y de sus acreedores. No es de extrañar, pues, que jamás llegase a considerarse seriamente esta posibilidad, pese a las observaciones formuladas al respecto, hasta las mismas vísperas de la expulsión, por quienes diagnosticaron las causas del fracaso de las campañas cristianizadoras. Los moriscos, por su parte, conscientes de la inviabilidad de lo que se pedía, y sin duda para evitar una reacción adversa de sus señores, no volverían a insistir en ello -a diferencia de lo que harían algunos eclesiásticos- en las nuevas demandas que dirigirían a la monarquía española.

Sin embargo, en ese momento excepcional, los representantes de las aljamas enunciaron con admirable concisión las condiciones generales de la permanencia de la población musulmana en el reino valenciano. Puede discutirse, sin duda, la exactitud del enunciado, pero sus tres aspectos -rentas elevadas, obligaciones serviles y sujeción a la tierra- se identifican con claridad suficiente como para plantear una indagación sobre su genealogía. Tal es el propósito del presente artículo.

\section{«MUCHOS PECHOS»}

Debido a una serie de factores que no podemos entrar ahora a considerar, la conquista cristiana del territorio que, desde 1239, sería el reino de Valencia, no produ-

1. Texto publicado por Boronat, Pascual: Los moriscos españoles y su expulsión. Estudio histórico-crítico, Valencia: Imprenta de Francisco Vives y Mora, 1901 (2 vols.), I, pp. 425-426. 
jo una extinción general de las comunidades andalusíes. La experiencia anterior de Mallorca, donde toda la población nativa desapareció con rapidez, no debe hacernos olvidar que esta opción existía y que su ejecución era perfectamente factible a través de mecanismos tan expeditivos como el cautiverio a gran escala y las deportaciones organizadas. De hecho, estas prácticas no estuvieron en absoluto ausentes a lo largo de la prolongada empresa militar catalano-aragonesa en el territorio valenciano; lo que sucede es que tuvieron un alcance limitado, permitiendo que permaneciera en el país una porción importante de sus antiguos habitantes, quizá en torno a la mitad de los que había antes de la irrupción cristiana. La permanencia no se encuadró a nivel general en ninguna forma de continuidad del antiguo orden político musulmán, como las que conocieron, por algún tiempo, la isla de Menorca o los «protectorados» castellanos de Murcia, Niebla y Jerez. Este hecho es relevante porque sin un referente legal ni una estructura administrativa comunes a toda la población andalusí sometida, no era posible mantener en la práctica los principios y procedimientos de la fiscalidad anterior a la conquista.

Hubo, no obstante, algunas excepciones. El territorio de Montesa y Vallada fue conservado durante tres décadas, hasta 1277, por los antiguos quwwâd de Xàtiva, los Banû 'Îsà. En la Marina se consintió que una decena de castillos permaneciesen administrados, bajo estrecha vigilancia cristiana, por tres familias de quwwâd andalusíes que no pudieron sostenerse más allá de 1270. También en esta zona meridional tuvo lugar el breve experimento (aproximadamente entre 1279 y 1290) del llamado almoixerifat de las Montañas del reino de Valencia, donde un oficial (muhtasib, mušrîf) musulmán organizó, en nombre del rey, la recaudación tributaria de una docena de distritos castrales. Finalmente, está el caso del $r a$ 'îs de Crevillent, incorporado tras la conquista del reino de Murcia por Jaime II, que perduró hasta 1318 y representa el último vestigio de autoridad musulmana conservado en el ámbito de la Corona de Aragón. Se trató, sin duda, de experiencias inconexas, muy localizadas y poco duraderas, pero en su momento constituyeron un referente vivo para conjuntos más amplios de comunidades musulmanas que, más allá de la costumbre, debieron identificarse con la estructura tributaria mantenida en dichos reductos y la usaron, con mayor o menor fortuna, como base de negociación en unos momentos cruciales. Con toda probabilidad, el mantenimiento de elementos del antiguo orden fiscal en la nueva estructura de las rentas pagadas por ciertas aljamas tuvo mucho que ver con dichas experiencias ${ }^{2}$.

Ahora bien, estas consideraciones no deben hacernos perder de vista algo fundamental, como lo es la atomización del cuerpo social musulmán del reino Valencia. Evidentemente, la ausencia del más mínimo resto de administración general para lo

2. TORRÓ, Josep: «Las conquistas latinas y los órdenes fiscales antiguos en el Mediterráneo (siglos XIIXIV)», en GALÁN, A. (ed.): Fiscalidad y sociedad en el Mediterráneo bajomedieval, Málaga, (en prensa); ibíd.: El naixement d'una colònia. Dominació i resistència a la frontera valenciana (1238-1276), Valencia: PUV, 2006 [1 $1^{\text {a }}$ ed. 1999], pp. 199-213; GUICHARD, Pierre: «Un seigneur musulman dans 1'Espagne chrétienne: le râ'is de Crevillente (1243-1318)», Mélanges de la Casa de Velázquez, Madrid, 1973, 9, pp. 283-334. 
que quedaba de la población andalusí, convirtió a la aljama ( $\hat{y} a m \hat{a}^{\prime} a$ ) o comunidad local en la unidad de encuadramiento sobre la que debía sostenerse la permanencia de los musulmanes en el nuevo orden político y social del reino cristiano ${ }^{3}$. Con todo, este hecho no era sino consecuencia de otra fragmentación más decisiva: la división del territorio en señoríos. Sólo el rey podría haber conservado o recreado una estructura tributaria común para los musulmanes del reino, pero la mayoría de las aljamas -y cada vez más con el paso del tiempo-pertenecían a diferentes señores laicos o eclesiásticos ${ }^{4}$.

El desmantelamiento o, en su caso, la desnaturalización de la antigua fiscalidad andalusí se llevaron a cabo de un modo diferente en cada señorío, dando lugar a una multitud de haces de rentas señoriales. Prácticamente cada solución local tuvo sus propias peculiaridades, condicionadas en parte por factores geográficos, pero que también tenían mucho que ver con las características de la aljama y las de la autoridad señorial de la que dependían. La persistencia de una organización comunitaria sólida y operativa favorecía la capacidad de negociación y, por tanto, las prolongaciones del antiguo orden tributario en el marco de las nuevas obligaciones debidas a los señores; el hecho de pertenecer al rey también propiciaba, normalmente, los elementos de continuidad. En el extremo opuesto, sin embargo, tendríamos las aljamas y morerías reconstituidas por iniciativa cristiana, mediante reasentamientos realizados en las inmediaciones de las villas de colonización; estas comunidades carecían de vínculos orgánicos de continuidad con el pasado andalusí y, consecuentemente, respecto a las antiguas estructuras fiscales. Entre ambos extremos, la intervención señorial en la configuración de los nuevos cuadros de rentas distaba de ser uniforme.

La diversificación local de las cargas plantea la dificultad de ofrecer una imagen válida para el conjunto de las aljamas del reino. No obstante, sí que puede señalarse un rasgo común que, además, compensa en cierta manera los efectos de la mencionada variedad. Me refiero a las tendencias simplificadoras de los conceptos impositivos. La estructura tributaria andalusí anterior a la conquista representaba justo lo contrario: un orden centralizado y jerarquizado, basado en principios fiscales de alcance general, que se imponía sobre comunidades locales solidarias, y en el que la moneda constituía la mediación esencial ${ }^{5}$. Los pagos fiscales, en efecto, se realizaban principalmente en moneda; en moneda se pagaban no sólo las exacciones comunitarias irregulares, conocidas como alfarda (ár. farda, 'contribución'), similares a las peitas cristianas, sino

3. Son interesantes, a este respecto, las consideraciones de CATLOS, Brian A.: The Victors and the Vanquished. Christians and Muslims of Catalonia and Aragon, 1050-1300, Cambridge-New York: Cambridge University Press, 2004, pp. 126-128.

4. GUINOT, Enric: «Los mudéjares de la Valencia medieval: renta y señorío», Áreas. Revista de ciencias sociales, Murcia, 1992, 14, pp. 29-47; ibíd.: «La creació de senyories en una societat medieval de frontera: el regne de València (segles XIII-XIV)», Revista d'Història Medieval, Valencia, 1997, 8, pp. 79-108.

5. BARCELÓ, Miquel: «Un estudio sobre la estructura fiscal y procedimientos contables del emirato Omeya de Córdoba (138-300/755-912) y del califato (300-366/912-976)», Acta Historica et Archaeologica Mediaevalia, Barcelona, 1984-1985, 5-6, pp. 45-72; GuICHARD, Pierre: Les musulmans de Valence et la Reconquête (XI ${ }^{e}$-XIII ${ }^{e}$ siècles), Damasco: Inst. Français de Damas, 1990-91, vol. II, pp. 247-257. 
también los impuestos relacionados con la parte más sustancial de la producción agraria, el llamado almagram (ár. magram, 'impuesto'); sólo los cultivos secos, en zonas de montaña o carentes de irrigación artificial se hallaban gravados con la exigencia en especie de una fracción de su producto, poco onerosa por cierto: el ' $u \check{s} r$ o diezmo «legal» ${ }^{6}$. La determinación de las cuantías monetarias imponibles a las tierras sujetas al almagram se realizaba a través de operaciones sofisticadas de estimación de la productividad en las que se tenía en cuenta la calidad del suelo, la frecuencia de los riegos y el tipo de cultivos; sus resultados eran objeto de registro y de revisión periódica. Esta complejidad fue la que vino a desaparecer tras la conquista, aunque siempre de acuerdo con pautas locales muy diferentes: si en unos casos sucedió de forma inmediata, en otros el proceso duró décadas y en algunos nunca se llegaron a perder del todo los procedimientos originales del almagram.

Con todo, el mantenimiento de fórmulas impositivas continuadoras o derivadas del almagram tuvo un alcance minoritario entre las aljamas, limitándose básicamente a zonas de realengo, como Eslida o la Vall d'Uixó, y a algunos señoríos importantes, como la Valldigna o las aljamas del condado de Dénia. Fue, además, muy desigual. Sólo parece haberse conservado un almagram similar al de época andalusí en las grandes aljamas del valle del Vinalopó - un hecho que cabría relacionar con la influencia ejercida por la autoridad musulmana de Crevillent hasta 1318-, mientras que en otros lugares lo que se mantuvo, en realidad, fueron los pagos en moneda, bien como agregación de censos sobre las tierras, bien como sumas fijas de dinero, sin que mediasen ya los antiguos sistemas de estimación periódica de la productividad agraria. Como se ha dicho anteriormente, la solidez de la comunidad rural -que no era un factor independiente de su antigüedad y tamaño- tenía mucho que ver con la adopción de este tipo de soluciones. Así, una probada capacidad de la aljama para constituirse en arrendataria de sus propios pagos podía desembocar en la concesión de un arrendamiento perpetuo como el otorgado por el duque real de Gandia, Alfonso el Viejo, a Gallinera-Ebo en $1401^{7}$.

La simplificación de los pagos se acompañó, al tiempo que la favorecía, de su intensificación. Es cierto, sin embargo, que el incremento de las cargas se dejó sentir con fuerza muy pronto, cuando aún se mantenían activos entre muchas comunidades regímenes fiscales heredados de antes de la conquista. De hecho, nada impedía que los antiguos principios impositivos pudiesen ser manipulados. Así, a partir de los años 1260 las alfardas, que originalmente debieron tener un carácter extraordinario, pasaron a convertirse en tributos anuales ${ }^{8}$. También era posible incrementar el valor monetario de las unidades de estimación que servían para determinar el almagram, llamadas alfa-

6. Ibíd., II, pp. 259-271.

7. TORRÓ, Josep: «Del almagram a las particiones de frutos. Las cargas agrarias en las aljamas musulmanas del reino de Valencia», en VALLEJo, R. (ed.): Los tributos de la tierra. Fiscalidad y agricultura en España (siglos XII-XX), Valencia: PUV, 2008, pp. 185-222, especialmente pp. 200-209.

8. GUICHARD, Pierre: Les musulmans..., II, pp. 268-271. 
bes (del ár. al-habba, 'grano de un racimo'), como se advierte en algunos lugares ${ }^{9}$. O suprimir, sencillamente, las exenciones fiscales de que gozaban determinados cultivos arbóreos, tal y como sucedió con higueras y algarrobos en la Vall d'Uixó a partir de $1302^{10}$. Por otra parte, la intensidad de las cargas soportadas por las aljamas después de la conquista no sólo puede valorarse respecto a los niveles de exigencia anteriores, sino también en relación a las que pesaban sobre las comunidades cristianas. En otro lugar he estimado que, hacia 1270, una unidad doméstica perteneciente a una aljama como la de Beniopa o Pego - donde las obligaciones fiscales de origen andalusí se mantenían aún como parte esencial del conjunto de las rentas- pagaba anualmente, cuanto menos, el doble que una familia de colonos cristianos de villas como Ontinyent o Alcoi, sumando a las rentas del rey el diezmo eclesiástico ${ }^{11}$.

Los gravámenes debidos por las aljamas a los señores se simplificaron a medida que los elementos supervivientes del antiguo régimen tributario eran sustituidos por las particiones de frutos como su componente esencial. En las comunidades reconstituidas a raíz de los desplazamientos interiores de la población musulmana se partió de cero y pudo imponerse de inmediato este tipo de renta, pero allí donde las aljamas permanecían en sus tierras, hubo que modificar las condiciones preexistentes: en unos casos simplemente se sustituyó el almagram por la exigencia de una quinta parte de las cosechas; en otros, se utilizó como base el diezmo «legal», agregándole una serie de recargos negociados que, al cabo, alcanzaban también fracciones del orden del quinto. De hecho, en el conjunto de las rentas musulmanas conocidas en el reino de Valencia durante la época medieval, las basadas en la partición al quinto parecen ser mayoritarias; y lo son, sin duda, si ampliamos este grupo a las del sexto y el cuarto. De hecho, según Manuel Ardit, en el siglo XVI las particiones establecidas en un cuarto serán las más destacadas. Conviene precisar que, por lo general, no se trata de una demanda genérica, sino de la partición aplicada a la tierra de regadío, combinada normalmente con fracciones similares exigidas para los frutos de árboles y otras menos rigurosas, del orden del diezmo (1/8 a 1/11) para cereales y viñedos de secano. Por otra parte, tampoco debe olvidarse que en la mayor parte de los lugares sometidos a este tipo de particiones no desaparecieron las demandas de pagos complementarios en moneda, continuadores de la tradición de la alfarda (aunque la denominación podía variar según señoríos). Esta parte de la renta señorial no estaba exenta de relevancia,

9. Por ejemplo, en Gallinera hacia 1296: Archivo de la Corona de Aragón [en adelante, ACA]: Real Cancillería [en adelante, RC], reg. 102, fols. 142v-143r.

10. FEBrer, Manuel V.: Cartas pueblas de las morerías valencianas y documentación complementaria, Zaragoza: Anúbar, 1991, n. ${ }^{\circ} 119$.

11. TORRó, Josep: «Colonització i renda feudal. L'origen de la peita al regne de València», en Col·loqui Corona, municipis i fiscalitat a la Baixa Edat Mitjana, Lleida: Institut d'Estudis Ilerdencs, 1997, pp. 467-494, especialmente pp. 487-490; ibíd.: El naixement..., pp. 226-227. 
ya que podía equivaler a un $15 \%$ del valor de los frutos correspondientes a las particiones $^{12}$.

Geográficamente, las aljamas que pagaban un quinto (o entre un sexto y un cuarto) de su producción agraria se localizaban en la región central del reino y, particularmente, en los valles altos del Palancia, el Júcar y el Turia, donde las tierras favorecidas por algún tipo de riego proporcionan la parte substancial de las cosechas. No obstante, en las huertas de Xàtiva y Gandia, así como en la comarca de Cocentaina, las particiones exigidas a los campesinos musulmanes eran bastante más severas. Aquí los señores tomaban una tercera parte del producto de los campos irrigados, prácticamente lo mismo en el secano - un tercio o un cuarto- y nada menos que la mitad del aceite y de los frutos arbóreos, más aún si se tienen en cuenta los variados recargos. En estos casos los censos en moneda no eran inexistentes, pero representaban una proporción pequeña dentro del elevado monto de las cargas. Pese a su rigor, se trata de una modalidad de renta bastante extendida y documentada con cierta frecuencia, al menos a partir de finales del siglo XIV. Cabe señalar, asimismo, que el escenario de este tipo de exigencias suele ser, en la práctica totalidad de los casos, el de un señorío pequeño, constituido sobre una sola alquería que no supera las 20 o 25 unidades familiares. Los campesinos que moran en estos lugares se caracterizan por un escaso arraigo y, pese a ser calificados de «enfiteutas»-y de «heredades» las tierras que se les asignan- tienden a confundirse con los aparceros (exaricos, exameces) que el señor puede expulsar a voluntad, de los que apenas se distinguen en la práctica ${ }^{13}$.

La coherencia territorial de los cuadros de rentas basados, respectivamente, en el quinto y el tercio es comprensible si tenemos en cuenta las migraciones de corto radio protagonizadas por los campesinos musulmanes, puesto que permite amortiguar la competencia señorial generada en torno a la captación y asentamiento de éstos. Así, las condiciones vigentes en las diferentes alquerías del término de Xàtiva en el siglo XV parecen, hasta en los detalles, calcadas de un mismo modelo ${ }^{14}$. Por otra parte, la difusión de las particiones al tercio durante la misma época, con la degradación campesina que conllevaban, podría haberse visto favorecida por el cierre de las fronteras del reino a la emigración musulmana, legalmente definitivo, como veremos más adelante, a partir de 1403 .

Entre el campesinado cristiano las particiones no eran desconocidas ni infrecuentes, aunque no se superaba el nivel de exigencia marcado por el quinto, y cuando

12. TORRÓ, Josep: «Del almagram...», pp. 194-200, 212-213; ARDIT, Manuel: «Els moriscos valencians. Una reflexió (parcialment) alternativa», en L'expulsió dels moriscos. Conseqüències en el món islàmic $i$ el món cristià, Barcelona: Generalitat de Catalunya, 1994, pp. 72-85, especialmente p. 80.

13. TORRÓ, Josep: «Del almagram...», pp. 213, 220-222; PlA, Primitivo J.: «Acerca de los contratos agrarios de los mudéjares valencianos: los 'capítols' de Catamarruc», Anales de la Universidad de Alicante. Historia Medieval, Alicante, 1983, 2, pp. 119-138; ibíd.: «La carta puebla de Señera en 1445», Anales de la Universidad de Alicante. Historia Medieval, Alicante, 1992-1993, 9, pp. 279-295.

14. Véanse los casos publicados por FEBRER, Manuel V.: Les aljames mudèjars valencianes en el segle XV, Valencia: PUV, 2006, n. ${ }^{\text {os }} 52,55,56,58,60,88$ y 89. 
llegaban al mismo, no se acompañaban de cargas complementarias equiparables a las soportadas por los musulmanes. A mediados del siglo XV, los musulmanes de las baronías de Cheste y Vilamarxant debían responder al señor de una quinta parte del producto de las tierras de regadío, mientras los vasallos cristianos «solament» el diezmo íntegro; en el señorío de Llombai, por la misma época, mientras los musulmanes satisfacían particiones del cuarto y el tercio, los vecinos cristianos se limitaban a entregar el diezmo y la primicia ${ }^{15}$. Por lo demás, predominaba la tierra franca y, cuando no, los censos en dinero; el pago en especie al rey o a los señores se limitaba, normalmente, al tercio diezmo, y quedaban las particiones como formas de renta minoritarias, limitadas a señoríos nobiliarios y eclesiásticos de la fértil llanura litoral del centro del reino, en torno a la capital, entre la Plana de Castellón y la Ribera. Éstas, en general, ofrecían condiciones menos gravosas, y en varios casos fueron objeto de disminuciones que contrastan con la tendencia inversa observada en las aljamas musulmanas ${ }^{16}$. Si ya en 1248 Jaime I había reconocido a los aristócratas heredados en el reino que, si se expulsaba a los musulmanes, «la renda vos en baixarà, que no us valdrà tant per crestians com per sarraïns», con mayor motivo Beatriu de Cardona, señora de Callosa d'en Sarrià, podía afirmar en 1486 que «més renda e més profit donen los vasalls moros que no fan los cristians vasalls» ${ }^{17}$. Y tanto. Un memorial de 1412 nos permite comparar las rentas de la Pobla de Vallbona, habitada por cristianos, con las de la aljama musulmana de Benagusail, perteneciente también al rey y situada casi a sus puertas, compartiendo el mismo medio agrario del valle del Turia; las primeras ascienden a $7.393 \mathrm{~s} .3 \mathrm{~d}$. y las segundas a 26.858 s. 8 d., lo que indica en términos de promedio, considerando datos demográficos muy fiables de fines del siglo XV, una carga de $44 \mathrm{~s}$. por cada hogar cristiano frente a la de 107 s. que pesa sobre los musulmanes: casi dos veces y media más. Todo esto sin tener en cuenta las dimensiones de las heredades, presumiblemente más pequeñas en el caso de los segundos ${ }^{18}$.

\section{«MUCHAS SERVIDUMBRES»}

Las particiones de frutos brindaron a los señores - $\mathrm{O}$ a los eventuales arrendatarios que actuaban en su lugar- la oportunidad de extender poderosos resortes de disciplina y control del campesinado musulmán. En primer lugar, depositaban en sus vasallos la responsabilidad de transportar las fracciones correspondientes de las cosechas a los almacenes o a la residencia del señor, quedando obligados a los consiguientes servicios

15. Ibíd., n. ${ }^{\circ} 65$ (1445); GosÁLBEZ, Elia: «Cristianos, mudéjares y moriscos en el marquesado de Llombai», Revista de Historia Moderna, Alicante, 1998-1999, 17, pp. 195-218, especialmente pp. 198-203.

16. GuINOT, Enric: Cartes de poblament medievals valencianes, Valencia: Generalitat, 1991, pp. 37-39.

17. Llibre dels feits, ed. SoldEVILA, F.: Les quatre grans cròniques, Barcelona: Ed. Selecta, 1971, cap. 366; SALVÀ, Adolfo: La villa de Callosa de Ensarrià, Alicante: Diputación, 1960, p. 55.

18. Memorial publicado por FEBRER, Manuel V.: Les aljames mudèjars..., n. ${ }^{\circ} 30$; los datos demográficos en VALLDECABRES, Rafael: El cens de 1510. Relació dels focs valencians ordenada per les corts de Montsó, Valencia: PUV, 2002, pp. 549, 555. Según el censo de 1488 (refrendado por otros cuatro recuentos hasta 1510), la Pobla de Vallbona contaba con 168 vecinos, Benaguasil con 251. 
de acarreo. En segundo lugar, dado que el producto debía entregarse en condiciones de ser almacenado o comercializado, se exigía la preparación del mismo, agregando así a la partición un importante servicio en trabajo. Es significativo que, en casi todos los casos, no se demandase una fracción de las olivas, sino del aceite, una vez elaborado en la almazara del señor. La vendimia conllevaba, igualmente, la vinificación de la parte señorial; una exigencia que pesaba, particularmente, sobre las aljamas del valle del Turia y otras del centro del reino, donde los musulmanes debían hacerse cargo de pisar las uvas, trasegar el vino, lavar trujales y tinajas, etc. En el caso del lino, un cultivo especialmente significativo entre las aljamas rurales, y orientado de forma destacada a las necesidades domésticas, advertimos repetidamente que la parte señorial de la cosecha debe entregarse en forma de manojos que previamente ya hayan sido enriados, machacados y espadados. La subsiguiente hilatura del lino es, asimismo, objeto de la intervención señorial a través de la demanda coactiva de una parte de su producto, normalmente una libra de hilaza y otra de estopa por cada casa, con variaciones poco significativas. En tercer lugar, dado que los castillos, graneros, cilleros, almacenes, lagares y otras instalaciones señoriales donde se depositaban los frutos, requerían trabajos constantes de conservación y mantenimiento, los señores terminaron exigiendo a sus vasallos musulmanes servicios de limpieza y obra prácticamente ilimitados ${ }^{19}$.

La gestión de las fracciones de cosechas satisfechas en el régimen hegemónico de las particiones ofrecía, como hemos visto, un amplio campo para el desarrollo de las servidumbres, pero no los dispositivos jurídicos que permitían justificarlas y regularlas. En este sentido, el punto de partida debe situarse en la usurpación señorial de una obligación comunitaria anterior a la conquista, la llamada «sofra» o azofra (ár. sujra), relacionada con la reparación de los recintos fortificados y su aprovisionamiento de agua y leña ${ }^{20}$. La ampliación del contenido original de la azofra resultaba relativamente sencilla en la medida que los antiguos husûn (en su gran mayoría fortificaciones rurales comunitarias eventualmente utilizadas por el Estado) se convertían en castillos señoriales. Como se advierte en las cartas de Eslida de 1276 y 1409, esta obligación podía derivar con facilidad a un servicio de suministro gratuito de carne y huevos al alcaide $\mathrm{y}$, sobre todo, al señor de la fortaleza ${ }^{21}$. Dicho servicio podía desviarse, igualmente, a la verdadera residencia señorial, situada más lejos, en las ciudades de Valencia, Alzira o Xàtiva. Así, el compromiso de acarrear, sin retribución alguna, la parte señorial de los frutos, provisiones diversas y cargas de combustible hasta las casas urbanas de los

19. TORRÓ, Josep: «Del almagram...», pp. 215-216.

20. GuICHARD, Pierre: «Le problème de la sofra dans le royaume de Valence au XIII ${ }^{\mathrm{e}}$ siècle», Awrâq: Estudios sobre el mundo árabe moderno y contemporáneo, Madrid, 1979, 2, pp. 64-71.

21. GuINOT, Enric: Cartes de poblament..., n. ${ }^{\text {ss }} 165$ (1276) y 305 (1409). La carta de Bes, de 1266, exime expresamente, entre otras, de las prestaciones de gallinas, espaldas y huevos, que probablmente habían sido exigidas por el alcaide de dicho castillo a las alquerías de Yátova, Mijares, Torís, la Cova, la Pardinella y la Bacolla (ibíd., n. ${ }^{\circ} 132$ ). 
señores aparece formalizada normalmente en capítulos de población de aljamas a partir de $1300^{22}$.

En principio, las corveas o jornadas de trabajos no retribuidos, a discreción del señor, tenían un alcance bastante limitado, de uno a cinco o seis días al año, según lugare $^{23}$. Ahora bien, los servicios carentes de retribución no se limitaban necesariamente a ese número fijo de días. Se sustituían o complementaban con tareas específicas de carácter forzoso, destajos gratuitos que quedaban al margen de cualquier cómputo preciso de jornadas. De hecho, las azofras originales o peonadas propiamente dichas, terminaron por perder interés para el señor, conmutándose, en muchos casos, por pagos fijos en dinero, cargados sobre las unidades familiares o sobre el conjunto de la aljama ${ }^{24}$. Los destajos obligatorios no sólo se dedicaban a la preparación del lino, la hilatura de sus fibras y las tareas relacionadas con la vendimia, cuya importancia ya se ha destacado anteriormente, sino también al mantenimiento de los sistemas de riego y la plantación de árboles. Podemos pensar, sin duda, que estas últimas tareas también interesaban a los campesinos, pero al formalizar los servicios de monda de acequias y reparación de azudes el señor se desentendía de la parte que pudiera corresponderle por sus huertas y molinos ${ }^{25}$. Era, también, una medida de cautela para prevenir eventuales comportamientos de dejadez por parte de campesinos poco arraigados, proclives a la emigración e, incluso, a la huida. Esta impresión se refuerza por el hecho de que en

22. Ibíd., n. ${ }^{\text {s }} 232$ (Buñol, 1300), 291 (Cheste, 1371), 307 (Sumacàrcer, 1417), 313 (Agost, 1482); FEBRER, Manuel V.: Les aljames mudèjars..., n. ${ }^{\text {os }} 4$ (Llombai y Catadau, 1377), 25 (Gestalgar, 1407), 40 (Alcàsser, 1417), 44 (Alcosser y Rafal, 1423), 65 (Vilamarxant y Cheste, 1445), 69 (Benaguasil, 1454), 81 (Anna, 1466), 82 (Picassent, 1467), 86 (Godelleta, 1471), 101 (Benaguasil, 1483), 108 (Betxí, 1500), 115 (Carlet y Benimodo, 1520). Pueden añadirse otros casos, como el de Sot de Ferrer (1394), cuya carta publican GUINOT, Enric, y CERVANTES, Francisco J.: «Conflictes agraris en les senyories de musulmans valencians: les cartes de poblament de Bernixes (Vilamalur) i Sot de Ferrer (segles XIV i XV)», Boletín de la Sociedad Castellonense de Cultura, Castellón de la Plana, 1996, LXXII, pp. 209-237, doc. 2; o el de Nàquera (1416, septiembre, 5), Archivo de Protocolos de Valencia: n. ${ }^{0} 1.317$.

23. Entre los casos más extremos se hallan los siete dias al año de Alèdua hacia 1444 (GosélBEZ, Elia, «Cristianos, mudéjares...», pp. 207-208), o los seis días de Gaibiel en 1379 (FEBRER, Manuel V.: Les aljames mudèjars..., n. ${ }^{\circ}$ 5). En Sot de Ferrer (1394) se exigen cinco peonadas o «jornales de çofra en cada un anyo» (GUINOT, Enric, y Cervantes, Francisco J.: "Conflictes agraris...», doc. 2), como se hacía, desde 1284 al menos, en Gestalgar: PASTOR, Manuel: El Cartulari de Gestalgar. Memòria escrita d'un senyoriu valencià, Barcelona: Fundació Noguera, 2004, n. ${ }^{\circ}$ 5. En la carta de Perputxent de 1285 se establecen seis peonadas anuales, pero pueden rebajarse según la aportación de bestias de carga (GUINOT, Enric: Cartes de poblament..., n. ${ }^{\circ}$ 213). En los capítulos de Cheste (1371), en principio, no se fijan límites: «tota hora que nós e los nostres vos aurem menester... e en aquell loch que a nós e als nostres plaurà» (ibíd., 291). Un caso especial es el de Villastar, en el Bajo Aragón, donde la orden del Temple exige una peonada mensual, aunque el establecimiento no tendrá éxito (FEBRER, Manuel V.: Cartas pueblas ..., n. ${ }^{\circ} 132$ ).

24. Del primer caso pueden servir como ejemplos las cartas de Xivert (1359), 12 s. por casa (GUINOT, Enric: Cartes de poblament..., n. ${ }^{\circ} 271$ ), o Chelva (1370), 4 s. (ibíd., n. ${ }^{\circ} 290$ ); del segundo, la ya citada (nota 22) de Nàquera (1416), cuya aljama paga una sofra anual de $185 \mathrm{~s}$.

25. Ibíd., n ${ }^{\text {os }} 300$ (Sumacàrcer, 1403) y 303 (Ribesalbes, 1405). 
algunas cartas del siglo XV se especifiquen las labores y riegos que cada vasallo debe realizar en la heredad que le ha sido asignada ${ }^{26}$.

A pesar de la relevancia indudable de todas estas servidumbres o servicios obligatorios, realizados sin compensación, «debades e sens algun preu», podríamos decir que su aspecto más importante reside en que la negociación de los mismos abrió la puerta a los retribuidos. Ya se ha dicho que uno de los empleos más apreciados de los servicios retribuidos era el de las obras en los castillos y en otras dependencias señoriales, como graneros, molinos o almazaras, además de los acarreos a las residencias urbanas de los señores, aunque también se utilizaban ampliamente para cavar las viñas y huertos de éstos. Las reservas señoriales, en efecto, contra lo que a veces suele darse por sentado, no eran inexistentes ni carentes de importancia en muchos lugares habitados por musulmanes. Podía ser, como la de la pequeña alquería de Alferratzí (23 casas), en la huerta de Gandia, «un hort de senyor gran e bell, clos de tàpies tot entorn», según se dice a fines del siglo XIV. Calidad, pero también cantidad: en Alcàsser, hacia 1417, el señor, además de su huerto, tiene como propias 48 hanegadas ( 4 ha) de viña «de grech malvesia e montonech» que los habitantes del lugar están obligados a cavar y binar a cambio de una magra retribución de 16 dineros diarios que, además, es posible que el señor no pagara en efectivo, pues podía descontarla de las deudas reconocidas por sus vasallos musulmanes ${ }^{27}$. Probablemente la expansión de la caña de azúcar en el siglo XV reavivó el interés de los señores de la comarca de la Safor por ampliar, mejorar y proteger sus huertos cercados, aunque también es cierto que la afectación forzosa de una buena parte de las tierras de sus vasallos musulmanes al suministro del trapiche (165 hanegadas, casi 14 ha, en la pequeña Alqueria de Roca hacia 1471) hacía innecesario constituir una gran reserva señorial ${ }^{28}$.

Fueron los servicios remunerados los que a la postre resultaron verdaderamente decisivos en la conformación definitiva de los resortes de control señorial sobre las actividades de los vasallos musulmanes. Y esto por una razón muy sencilla: mientras las peonadas no pagadas debían observar, necesariamente, unos límites (cierto número de días al año o determinadas tareas concretas, cuando no estaban simplemente conmutadas), las remuneradas carecían por completo de tales restricciones. El señor podía exigir servicios para las obras o actividades que considerase oportuno en el momento que le conviniese. Pagando, sí, pero pagando retribuciones tarifadas inferiores -a

26. Por ejemplo, en Senyera en 1445 (PLA, Primitivo J.: «La carta puebla...», p. 289).

27. FeBrer, Manuel V.: Les aljames..., n. ${ }^{\text {os }} 15$ (Alferratzí, 1398) y 40 (Alcàsser, 1417). Cabe añadir que, no obstante la remuneración del trabajo en las viñas, los musulmanes de Alcàsser debían sarmentar, vendimiar, pisar la vendimia, trasegar el vino y lavar las jarras «tot francament, sens que lo dit senyor no·ls és tengut donar loguer ni tribut algú, ne encara a menjar».

28. GISBERT, Josep A.: «Arquitectura, arqueologia i empremta material del sucre a la Safor: trapigs i enginys del duc», en GisBert, Josep A. (ed.): Sucre \& Borja. La canyamel dels ducs, Gandia: Generalitat Valenciana, 2000, pp. 109-154; FEBRER, Manuel V.: Les aljames..., n. ${ }^{\circ} 87$ (Alqueria de Roca, 1471): «són enteses e obligades coure en lo dit trapig totes les canyamels e fanecades que per a present són plantades e obligades al dit trapig, les quals són CLXV digidides, e les que de ací avant de plantaran en la dita alqueria durant lo dit arrendament». 
veces muy inferiores- a la cuantía de los salarios comunes recibidos por los jornaleros cristianos en las villas y ciudades del reino. Se fijaban, además, por largos períodos de tiempo, normalmente mientras tenían vigencia los capítulos de población, por lo que su valor real tendía a disminuir. A fines del siglo XIV e inicios del XV la cuantía media de las remuneraciones tarifadas impuestas por los señores a los musulmanes no llegaba a los 10 dineros diarios; mientras, en la ciudad de Valencia, un peón no cualificado ganaba unos 30 dineros por cada jornada de trabajo ${ }^{29}$.

Por otra parte, los servicios obligatorios o servitutibus no se limitaban a la prestación de jornales, peonadas y destajos, sino que incluían, asimismo, el suministro de productos generados en el ámbito doméstico. Igual que sucedía con las peonadas, coexistían las obligaciones gratuitas, más o menos limitadas, con las remuneradas carentes de límite. En general, casi todas las aljamas del reino se hallaban sometidas a la obligación de entregar un par de gallinas anuales por cada unidad familiar. En algunos casos, se acompañaba de la exigencia de una espalda de cordero, un par de pollos, ristras de ajos y cebollas o una carga de leña seca; en Sumacàrcer cada familia debía entregar un huevo a la semana. Por su parte, los suministros retribuidos se hallaban sujetos a tarifas fijas en cada señorío, con ligeras variaciones locales. En el siglo XIV los señores podían comprar a sus vasallos musulmanes todas las gallinas que quisiesen a un precio que iba tan sólo de 4 a 12 dineros el ejemplar. En algunos lugares los capítulos de población de la primera mitad del siglo XV elevaron la tarifa a entre 14 y 18 dineros, pero en la misma época, en la ciudad de Valencia, las gallinas costaban entre 20 y 38 1/2, con un precio medio de 28,7 dineros, es decir un $67 \%$ más si tomamos como referencia la tarifa más elevada y más del doble si consideramos la menor; sin olvidar que en otras aljamas se mantenían aún las tarifas de 4 o 6 dineros por gallina, de cinco a siete veces inferiores al precio de los mercados ${ }^{30}$. Con un solo dinero el señor compraba de tres a ocho huevos, según aljamas, mientras en la villa de Alzira ese era el precio que podía costar apenas un par de huevos ${ }^{31}$.

29. Ha publicado una útil tabla de los salarios tarifados FEBRER, Manuel V.: «El arrendamiento de servicios agrícolas y sus formas de remuneración en las aljamas mudéjares valencianas», en VI Simposio Internacional de Mudejarismo, Teruel: Centro de Estudios Mudéjares, 1995, pp. 297-309. Los salarios de Valencia, en Hamilton, Earl J.: Money, Prices and Wages in Valencia, Aragon and Navarre, 13511500, Cambridge, Massachussetts: Harvard University Press, 1936, pp. 273-279.

30. Los datos de Valencia corresponden a los años 1413-1449, tabulados por Hamilton, Earl J.: Money, Prices..., pp. 215-217. Un caso especial es el de la carta de Ribesalbes (1405), donde se distinguen las gallinas morisques, tarifadas a 16 dineros, y las majors, que se pagarían a entre 20 y 22 dineros, según estimación conjunta del alamín y el alcaide (GuINOT, Enric: Cartes de poblament..., n. ${ }^{\circ} 303$ ).

31. LAIRÓn, Aureliano J. (ed.): Libre de diverses statuts e ordenacions fets per lo consell de la vila de Algezira, Valencia: PUV, 2001, p. 69 (fines del siglo XIV). En las valoraciones de gallinas y huevos se han tenido en cuenta las tarifas contenidas en diversas cartas o arrendamientos publicados: GUINOT, Enric: Cartes de poblament..., $\mathrm{n}^{\text {os }} 213$ (Perputxent, 1285), 261 (Valle de Ayora, 1328), 264 (Perputxent, 1334), 271 (Xivert, 1359), 288 (Chelva, 1370), 291 (Cheste, 1371), 300 (Sumacàrcer, 1403), 303 (Ribesalbes, 1405), 307 (Sumacàrcer, 1417); PASTOR, Manuel: El Cartulari de Gestalgar..., n. ${ }^{\circ} 5$ (Gestalgar, 1284); Febrer, Manuel V.: Cartas pueblas..., n. ${ }^{\circ} 117$ (Buñol, 1318); Ibíd., Les aljames..., n ${ }^{\text {os }} 5$ (Gaibiel, 1379), 8 (Llombai, 1381), 21 (Monòver-Xinosa, 1405), 25 (Gestalgar, 1407), 41 (Benieto, 1418), 92 
Es interesante advertir que, a diferencia de lo que sucede con las rentas propiamente dichas, que deben negociarse con la aljama y formalizarse en capítulos escritos, la demanda de servicios permite un ejercicio de las presiones señoriales más informal, más individualizado y, sobre todo, sin techos de exigencia demasiado claros. Ésta será, pues, la vía escogida por los señores para incrementar su nivel de explotación y control de las unidades campesinas musulmanas. En consecuencia, será también la causa principal de las quejas y los actos de resistencia más significativos protagonizados por las aljamas, pese a que el elevado volumen de pagos representado por las rentas ordinarias -particiones de frutos y pagos en moneda- podía parecer un asunto mucho más importante $^{32}$. A mediados del siglo XV, los campesinos musulmanes de Borriol emigraban a causa del mal trato señorial, que incluía la imposición de «filaces, gallines, pollastres, jornals» $\mathrm{y}$ otros servicios considerados «victigals nous e inusitats» ${ }^{33}$. Las reclamaciones contra los servicios en general, y los remunerados en especial, son frecuentes. Las aljamas pidieron mejoras en las tarifas establecidas por los señores, como muestra una multitud de ejemplos conocidos. Y es que la relevancia de estas demandas señoriales debe medirse, más bien, por su impacto a escala del ámbito doméstico, el marco de reproducción y la última retaguardia de la unidad campesina; su principal reserva de productos canjeables por moneda y, por supuesto, de proteínas. Criar más gallinas, más pollos, más corderos, más cabritos, producir más huevos y más leche... o privarse de su consumo; distraer más tiempo hilando y tejiendo lino, acarreando provisiones, reparando el castillo, limpiando los trujales o cavando en la viña del señor. Todo esto obligaba a reajustar la división doméstica del trabajo hasta unos niveles que los afectados podían considerar comprometedores para la propia capacidad reproductiva del grupo familiar.

El grado de imposición de los servicios obligatorios en las aljamas no fue, ciertamente, uniforme, ya que hubo diferentes procesos locales de tanteo y presión. Este hecho nos obliga a tener en cuenta las estrategias desplegadas por los señores a la hora de implantar y consolidar las servidumbres. El ejemplo de Sumacàrcer, cuya aljama amenazó en 1417 con abandonar masivamente el lugar si el señor no atendía a sus quejas, es una buena muestra del modo informal y furtivo a través del cual los señores pueden imponer servicios obligatorios. De las cuatro peticiones formuladas -que no vamos a detallar ahora-, la comunidad sólo consiguió que se atendiese a una, viendo rechazados los otros agravios, relativos a los suministros y jornales forzosos que no se hallaban contemplados en los capítulos de población de 1403 y que se habían introducido de modo subrepticio. Paradójicamente, la reclamación serviría para que el señor formalizase por escrito estos nuevos derechos «ultra lo dit stabliment», desatándose el malestar de los vasallos en 1429, con una pequeña revuelta en el transcurso de la cual

(Valldigna, 1478); BAÑó, Ricard: «La problemática mudéjar en Alcoi», Sharq al-Andalus. Estudios Árabes, Alicante, 1985, 2, pp. 39-47 (Uixola, 1448); también la carta de Nàquera de 1416 (vid. nota 22).

32. GUINOT, Enric: «Los mudéjares...», pp. 46-47.

33. Hinojosa, José: Los mudéjares. La voz del Islam en la España cristiana, Teruel: Centro de Estudios Mudéjares, 2002, vol. II, n. ${ }^{\circ} 155$. 
resultó levemente herida la señora del lugar ${ }^{34}$. Las negociaciones motivadas por las protestas de los campesinos podían eliminar o limar el alcance de alguna de las arbitrariedades, pero nunca conseguían restablecer el estado anterior de las cosas.

En esta dinámica los oficiales señoriales, particularmente los alcaides, desempeñan un papel crucial. La redacción de la carta de Gestalgar de 1284, por ejemplo, se justificaba por la necesidad de eliminar conflictos y dudas entre señor y vasallos, pero también entre éstos y los alcaides, «que demandan más algunas vezes que no manda el senyor». Las aclaraciones dieron lugar a unos capítulos especialmente gravosos en los que prácticamente ninguna actividad escapaba a la intervención señorial ${ }^{35}$. En 1300 la aljama de Buñol presentó una serie de agravios a su señor originados por las exigencias del alcaide y sus hombres, quienes les obligaban a darles ropa de cama para el castillo, a venderles gallinas según la tarifa señorial de 6 dineros la pieza, a cederles bestias de carga para transportar la harina al molino y a suministrarles leche gratuitamente un día a la semana. Los musulmanes se defendían señalando al señor que «a vós esto aprofetxa ninguna cosa, nin a vós es renda nenguna, e a nós es danyo», mostrando por el contrario su disposición a ofrecerle leche cuando estuviera él personalmente en Buñol. Pedro Ferrández de Híjar admitió las quejas, si bien al hacerlo se cuidó de asegurar y formalizar su derecho personal, como señor, a exigir servicios ilimitados de ropa, gallinas y leche; nada de esto se contemplaba en la carta original pactada entre la aljama y Jaime I en $1254^{36}$. Es muy significativo el caso de las aljamas de los dominios de la reina María de Luna (Alto Palancia), que en 1401 elevaron ante su señora muchas quejas contra los abusos de los alcaides, consiguiendo que se prohibiera a éstos demandar servicios en provecho propio, más allá de la simple percepción del salario que les abonaría el recaudador de las rentas señoriales. Sin embargo, apenas transcurridos dos años, considerando «moltes rahons que a açò nos mouen», la reina anuló dicha ordenación y dispuso una vuelta a «lo stament» anterior, con la única condición de que las exigencias de çofres y servituts por parte de los alcaides se limitasen a lo necesario para el aprovisionamiento de los castillos, lo que obviamente dejaba tales demandas al criterio de los propios alcaides. La rectificación de María de Luna refleja muy bien, sin duda, lo poco conveniente que resultaba para sus intereses comprometer la capacidad de actuación de quienes constituían, localmente, la punta de lanza del poder señorial ${ }^{37}$.

Por lo demás, éstos y otros muchos ejemplos muestran el funcionamiento de un ciclo bastante típico. Comienza con una vulneración progresiva de las condiciones establecidas en las cartas de población, protagonizada más bien por los oficiales señoriales, seguida de una protesta de las aljamas substanciada ante el mismo señor y, final-

34. Guinot, Enric: Cartes de poblament..., n. ${ }^{\circ}$ 307; Pons Alós, Vicent: El señorío de Sumacàrcer en la Baja Edad Media. De mudéjares a moriscos, Sumacàrcer: Associació d'Amics de l'Ermita de Sumacàrcer, 1995, pp. 52-55.

35. PAstor, Manuel: El Cartulari de Gestalgar ..., n. ${ }^{\circ} 5$.

36. GuINOT, Enric: Cartes de poblament..., n. ${ }^{\text {os }} 105$ (1254) y 232 (1300); ibíd., «Los mudéjares...», pp. $45-46$.

37. Febrer, Manuel V.: Les aljames..., n. ${ }^{\text {os }} 17$ y 18. 
mente, un remedio que limita los abusos pero consagra, al mismo tiempo, buena parte de las servidumbres establecidas de modo subrepticio. Las aljamas lo aceptan como mal menor. Este ciclo puede reproducirse varias veces a lo largo del tiempo con distintas intensidades y grados de resolución, lo que no impide distinguir algunos hitos cronológicos dentro de una tendencia general e irreversible al agravamiento. Pese a no faltar tentativas anteriores, el primer impulso serio parecen haberlo protagonizado aristócratas que aprovecharon las circunstancias favorables que siguieron al Privilegio de la Unión (1283), que sustrajo a los musulmanes de la tutela real, otorgando plena capacidad legal a nobles o ciudadanos para captar y asentar sarracenos laboratores en sus tierras, bajo condiciones negociadas, es decir, desprovistas de los derechos básicos reconocidos en las cartas de rendición establecidas a raíz de la conquista y las revuel$\operatorname{tas}^{38}$. Parece que fue inmediatamente después cuando se redactaron las primeras cartas que contienen un desarrollo detallado de servidumbres, como las de Gestalgar (1284) y Perputxent (1285). El segundo momento correspondería al final de la guerra con Castilla, que comportó la revuelta de buena parte de las aljamas de la zona central del reino, cuyo fracaso se refleja en cartas como las de Chelva (1370) y Cheste (1371) ${ }^{39}$. Un tercer estadio, más difuso, podría situarse entre las décadas iniciales y centrales del siglo XV, cuando los nuevos capítulos de población se hacen cada vez más detallados y vejatorios, coincidiendo con una revitalización de la aparcería e, igualmente, con las imposiciones de cultivos y servicios relacionados con la producción del azúcar en la comarca de la Safor y algunos otros lugares. Parece razonable creer que la prohibición de emigrar dictada a los musulmanes en 1403 propiciase esta nueva vuelta de tuerca.

Precisamente, el caso del azúcar merece cierta atención. Es dudoso que el despegue de la producción azucarera valenciana a partir de 1415 (año de construcción del primer trapiche en Oliva) y la magnitud alcanzada posteriormente por la misma hubiesen sido posibles sin la presencia del campesinado musulmán. Como, probablemente, tampoco lo habrían sido sin el desarrollo y consolidación previa del sistema de servicios obligatorios, específico de este campesinado. Pau Viciano ha descrito con precisión de qué modo las servidumbres señoriales impuestas al campesinado musulmán se pusieron a disposición de las compañías arrendatarias de los trapiches ${ }^{40}$. No sólo se vulneraba el dominio útil (forzando arrendamientos de parcelas a las compañías), los derechos comunitarios (el uso del agua de riego) o la capacidad de seleccionar los cultivos, sino que también se ponían en práctica las mecánicas serviles de los suministros tarifados (en la venta de la parte campesina de la cosecha de caña), de la obligatoriedad de los trabajos en el huerto señorial de caña y, por encima de todo, en el mismo trapiche: suministrar leña, acarrear, descodar y despedazar la caña, pasarla por el trujal, prensar, cocer el azúcar, envasarlo, transportarlo, efectuar la limpieza..., todo

38. ACA: RC, reg. 47, fols. 53r-54r; ALANYÀ, Lluís: Aureum opus regalium privilegiorum civitatis et regni Valentie, Valencia: Didaci de Gumiel, 1515 [en adelante se citará como $A O$ ], fol. 31v.

39. Ya citadas en la nota 31.

40. ViciANO, Pau: «Capital mercantil i drets feudals en la difusió de la canya de sucre al País Valencià. La senyoria d'Oliva a l'inici del segle XV», Afers, Catarroja; 1999, 32, 151-166. 
ello mediante la participación general de la aljama organizada en tandas, dividida en grupos y vigilada por sobrestantes cristianos. En realidad, más allá de las particularidades técnicas, no hay nada nuevo aquí, sino prácticas ampliamente arraigadas y experimentadas con anterioridad a la implantación de la producción azucarera. El despliegue físico de dichas instalaciones, en las morerías y alquerías de la Safor, se asociaría a concentraciones residenciales adyacentes, destinadas al alojamiento de los campesinos implicados en el proceso del azúcar. Pues, como decía el notario Joan Sart en 1453, el valor del trapiche no residía en el edificio ni en sus artefactos, sino «en la facultat de poder fer casa e haver terres e gents que facen la canyamel» ${ }^{41}$.

\section{«FORÇADOS D’ESTAR EN LOS LUGARES»}

Tener gente: esta es la cuestión fundamental. El desarrollo de las exigencias señoriales en materia de servicios suponía una condición previa, la de sujetar de forma duradera las unidades campesinas. Más allá de las servidumbres desigualmente impuestas, la restricción de la movilidad constituye el núcleo de la servidumbre, es decir, de la condición servil. Aunque legalmente los musulmanes del reino de Valencia son vasallos, no siervos hereditarios, adscritos a la tierra o unidos a sus señores por vínculos domésticos, sí que podemos hablar de una servidumbre de hecho, no exenta por cierto de un amplio y sólido respaldo jurídico. Hemos de plantear, pues, cuáles eran los resortes de fijación territorial que actuaban sobre el campesinado musulmán.

Un aspecto muy importante de la restricción señorial de la movilidad reside en el control de las facultades de enajenación y transmisión de la tenencia campesina. En los señoríos establecidos sobre aljamas se aprecia con frecuencia la voluntad de hacer permanentes las heredades, estableciendo un número fijo de ellas; una cantidad que se consideraría idónea para la viabilidad de las mismas como unidades campesinas y su rendimiento como sujetos de renta. Claro está, el intento de sustraer las heredades o tenencias campesinas a las dinámicas propias de una circulación sin trabas de las parcelas implica, como mínimo, señalar ciertos límites a los derechos de enajenación. Podían actuar como tales los luismos abusivos que, a veces, encontramos en los señoríos de población musulmana y que llegaban al $20 \%$, e incluso a una cuarta o una tercera parte del precio del bien enajenado, siendo así que los fueros del reino fijaban su importe en el $10 \%{ }^{42}$. Pero la forma de control más efectiva consistía en no permitir la

41. GISBERT, Josep A.: «Arquitectura...»; TORRÓ, Josep: «El urbanismo mudéjar como forma de resistencia: alquerías y morerías en el reino de Valencia (siglos XIII-XVI)», en VI Simposio Internacional de Mudejarismo, Teruel: Centro de Estudios Mudéjares, 1996, pp. 535-598, especialmente pp. 569-570 y 592. La cita de Sart, en GARCIA-Oliver, Ferran: «Les companyies del trapig», Afers, Catarroja, 1999, 32, 167-194, p. 194, donde añade que, sin usar de la autoridad señorial, «lo trapig no faria res, com stiga tot en mester de aygües, e de terres, fems e altres servituts».

42. Los campesinos de Chiva, Gestalgar, Godella y Perenxisa podían vender sus casas y parcelas irrigadas si pagaban al señor una quinta parte del precio: GuINOT, Enric: Cartes de poblament..., n. ${ }^{\circ} 238$ (1304); FEBRER, Manuel V.: Les aljames..., n. ${ }^{\circ} 86$ (1471). En Valldigna (1478) se distinguía el luismo de los musulmanes $(20 \%)$ del aplicado a los cristianos (10\%), como también en Carlet y Benimodo (1520), 
venta de una heredad sino a un musulmán foráneo, dispuesto a establecerse de inmediato en la misma con su familia y un equipamiento de labranza adecuado ${ }^{43}$. No se trataba, pues, de prohibir del todo las enajenaciones, ni de inmovilizar al tenente mediante un vínculo hereditario: mientras se garantizase la ocupación de las heredades por unidades substitutivas equivalentes, los hombres podían desplazarse. Así, la movilidad existía pese a todo, pero se realizaba no ya sin causar perjuicio alguno a los señores, sino en unas condiciones muy favorables para ellos $^{44}$. Estas prácticas eran coherentes con la estabilidad numérica y la homogeneidad de las unidades de explotación que, muy frecuentemente, advertimos en los señoríos habitados por musulmanes ${ }^{45}$. En algunas

aunque en proporciones más diferenciadas: $25 \%$ de los primeros frente a sólo el $5 \%$ de los segundos, que gozaban en este aspecto de un trato de favor a costa de una mayor penalización a las enajenaciones realizadas por musulmanes (FEBRER, Manuel V.: Les aljames..., n. ${ }^{\text {os }} 92$ y 115). Más extrema aun era la discriminación en el señorío de Llombai, donde los cristianos no pagaban luismo mientras los satisfechos por los musulmanes del lugar de Alfarb alcanzaban un tercio del precio (GOSÁLBEZ, Elia, «Cristianos, mudéjares...», pp. 203-204). La determinación del luismo como la décima parte del precio del bien enajenado, en el fuero IV.22.3: ColÓn, G., GArcíA, A., y GArcíA, V. (eds.): Furs de València, Barcelona: Ed. Barcino, 1980-2007 (11 vols.) [en lo sucesivo se citará como FV].

43. Esto se advierte con claridad en la Vall de Perputxent. Vid. TorRó, Josep y SEGURA, Josep Ma: «Irrigación y asentamientos en la Vall de Perputxent», en EpalzA, M. de (ed.): Agua y poblamiento musulmán, Benissa: Ajuntament, 1988, 67-92, pp. 76 y 84-86; también, GuINOT, Enric: Cartes de poblament..., n. ${ }^{\circ}$ 213: Quod positis vendere et alienare terram vestram mitendo in dicta terra alium qui teneat iugum et casatum, licet sit extraneus vel privatus.

44. Además del caso de Perputxent, citado en la nota anterior, este tipo de restricciones se expresa en otras muchas cartas, como las de Artesa (1302) o la de Cheste de 1371 (GuINOT, Enric: Cartes de poblament..., n. ${ }^{\text {os }} 234,291$ ); también la de Montroi de 1308 (FEBRER, Manuel V.: Cartas pueblas..., n. ${ }^{\circ}$ 132). En la de Ribesalbes, de 1405 (GuINOT, Enric: Cartes de poblament..., n. ${ }^{\circ}$ 303), se prohíbe la venta de bienes inmuebles a cualquier persona que no sea habitante de la alquería, y en caso de enajenarse una heredad completa - lo que implica el abandono del señorío- el titular se compromete a «dur per poblador un altre moro axí ydòneu o bo com ell». En Agost (1482), para que un musulmán pudiese abandonar su heredad era necesario que la enajenase a otro bajo la obligación de avasallarse en su lugar, o bien que ya fuese vasallo del mismo señorío, «per manera que la dita casa e orta y sequans no reste despoblada e sens vasalls» (ibíd., n. ${ }^{\circ}$ 313); una ordenanza similar se observaba en Gaibiel hacia 1379 (FEBRER, Manuel V.: Les aljames..., n. ${ }^{\circ}$ 5). Cuando, en 1417, los labradores de Sumacàrcer avisan de su intención de abandonar el lugar en grupo, el señor les advierte que sólo podrán hacerlo individualmente, tras vender cada heredad a un «bon llaurador» aceptado por él mismo, de modo que ésta no se quede ni un instante sin cultivador. Un aspecto interesante de este caso es que se hace notar el carácter habitual de la aplicación de estas disposiciones restrictivas («sovint se sdevé e acostuma») cuando los musulmanes vasallos de ciudadanos o miembros de la baja nobleza tratan de enajenar sus bienes inmuebles (GUINOT, Enric: Cartes de poblament..., n. ${ }^{\circ}$ 307). No he considerado otra restricción muy generalizada, la que impide vender tierras a cristianos, ya que pese a favorecer al señor (a los campesinos cristianos no pueden exigírseles todas las cargas y servicios impuestos a los musulmanes), también cuenta a favor del interés general de la aljama, bloqueando la posibilidad de intrusiones no deseadas por sus efectos disolventes y conflictivos.

45. Se entiende, así, que cuando el señor de Llombai establece, en 1381, el pago de un censo en dinero por cada heredad como derecho sobre las cosechas producidas en las tierras irrigadas, éste (que asciende a 60 s.) sea igual para todas (FEBRER, Manuel V.: Les aljames..., n. $\left.{ }^{\circ} 15\right)$. En Anna (1466) las 62 heredades establecidas pagan, cada una, un censo de reconocimiento de $14 \mathrm{~s} .3$ d. (ibíd., n. ${ }^{\circ} 81$ ). El perdón otorgado 
alquerías de la huerta de Xàtiva, en el siglo XV, se observa, incluso, una distinción de sus habitantes entre quienes tienen una heredad (que reciben la designación de llauradors), los que tienen media («miges heretats») y los llamados exameces (aparceros y otros que carecen de tierras de cultivo asignadas); también hay casos de labradores que poseen una heredad y media ${ }^{46}$.

Junto a las enajenaciones, el control de las transmisiones era igualmente relevante para los señores de aljamas. Cuando, en 1308, la orden del Hospital accedió a reconocer las heredades de sus vasallos musulmanes de Montroi, les impuso, entre otras condiciones, que los beneficiarios de testamentos y de donaciones nupciales se obligasen a residir personalmente en el lugar, así como a pagar un luismo equivalente a la décima parte del valor de los bienes transmitidos, contraviniendo expresamente lo establecido en los fueros del reino, que eximían de luismo y fadiga las transmisiones de bienes sujetos a censo ${ }^{47}$. En Llombai y Catadau (1381) era condición para poder heredar residir en el señorío, o bien vender la herencia a alguien que se comprometiese a hacerlo en lugar del heredero ${ }^{48}$. Todas estas ordenanzas equiparaban las transmisiones a las enajenaciones, extendiendo a las primeras las mismas trabas que afectaban a las segundas, pero no parecen haber sido el mecanismo más frecuente de actuación señorial en este sentido. Una difusión mayor tuvo, sin duda, el llamado «dret d'herències». Todo parece indicar que la imposición de este derecho se vio facilitada por la existencia de una costumbre anterior a la conquista, cuando las aljamas disponían de la capacidad de evitar que los patrimonios de su ámbito territorial se transmitiesen a miembros no residentes de la familia del difunto (aquí la costumbre local estaba por encima de las normas islámicas «igualitarias» en materia de herencia) ${ }^{49}$. Tras la conquista, los señores intervinieron estas prácticas para usarlas en su beneficio, asimilándolas al «mal uso» de la eixorquia (así se le llama en Onda, 1293) y desviando las reversiones a su patrimonio. En muchas aljamas, pues, pasaban directamente al señor los bienes

por el rey a la aljama de Quart tras la guerra de 1276-77 alude a heredades homogéneas de una jovada de extensión (GuINOT, Enric: Cartes de poblament..., n. ${ }^{\circ} 190$ ).

46. FeBrer, Manuel V.: Les aljames..., n ${ }^{\text {os }} 52$ (Alcúdia Blanca, hoy Rotglà, 1429); 58 (Faldeta, cerca de l'Ènova, 1431); 60 (Alqueria dels Frares, hoy Cerdà, 1431). Sobre los llamados exameces, ToRRó, Josep: «Exarics et exameces. Métayers musulmans et maîtres chrétiens dans le royaume de Valence $\left(\mathrm{XIII}^{\mathrm{e}}-\mathrm{XV}^{\mathrm{e}} \mathrm{s}.\right) »$, trabajo inédito presentado en el coloquio Le fait, la structure, le modèle et l'historien: l'Occident musulman médiéval dans l'oeuvre de Pierre Guichard (Lyon, 22-23 oct. 2004), en curso de publicación.

47. FEBrer, Manuel V.: Cartas pueblas..., n. ${ }^{\circ}$ 132: solvendo tamen... laudimium tantum videlicet decimam partem precii dictarum possessionum quas dederint vel legaverint... non obstante in aliquo foro Valentie. El fuero aludido es $F V$ : IV.23.41, donde se establece que las transmisiones de bienes censales, por testamento o matrimonio, no se hallan sujetas a luismo y fadiga.

48. FeBrer, Manuel V.: Les aljames..., n. ${ }^{\text {s }} 8$ y 9: «ab aquesta condició, que sia tenguda de star e habitar en lo dit loch e fer aquí residència personal e son cap major, o de fer venda e alienació [de] dites possessions e terres e cases a persona que stiga o habite e faça residència personal en lo dit loch».

49. TORRó, Josep: El naixement..., p. 209. 
del vasallo que fallecía sin hijos, o cuyos hijos residían fuera del señorío ${ }^{50}$. También se tiene constancia, como veremos, de la reclamación señorial a varones viudos de la herencia correspondiente al patrimonio propio de la esposa fallecida. Por otra parte, el «dret d'herències» podía identificarse con el rescate que, eventualmente, se pagaba para evitar estas confiscaciones o recuperarlas.

Las aljamas consideraron especialmente odiosa esta prerrogativa, llegando las de realengo a elevar una reclamación en 1338. Consiguieron, así, que se permitiese a los musulmanes vasallos del monarca sucederse en la titularidad de sus posesiones, con independencia del lugar concreto donde residiese cada uno ${ }^{51}$. Además, en 1350, el rey Pedro, para recompensar la fidelidad mostrada por los musulmanes de señorío durante la guerra de la Unión, les concedió el mismo derecho de sucesión que doce años atrás había otorgado a los de realengo. Los señores de vasallos musulmanes acogieron esta medida con hostilidad e hicieron todo lo posible por dificultar su aplicación, dando lugar a largos procesos judiciales. Finalmente, en 1403, los estamentos eclesiástico y militar consiguieron que el rey Martín anulase a efectos prácticos el privilegio de $1350^{52}$. De este modo, a partir de 1403, la posibilidad de que pudiesen heredar vasallos no residentes sólo se observaría, al parecer, en el ámbito de los dominios reales -siempre y cuando su aplicación no perjudicase a los intereses del rey-, así como en los del duque de Gandia. En 1437 el señor de Geldo podía afirmar que los señores con jurisdicción plena tenían la capacidad de apoderarse de las posesiones de sus vasallos musulmanes fallecidos cuyos hijos no residiesen en sus dominios, y que esto formaba parte de la consuetud del reino ${ }^{53}$.

El derecho de «prendre les herències dels moros» lo ejercían, en principio, los titulares de señoríos de mero imperio, no los de jurisdicción alfonsina que podían existir dentro de los primeros, y mucho menos los poseedores de minúsculas alquerías, sin jurisdicción alguna. En algunas zonas el señor de alta jurisdicción accedió, no sin conflictos, a compartir esta prerrogativa, como lo hicieron, a principios del siglo XV, el duque de Gandia o el barón de Oliva con los señores de alquerías existentes en los términos de sus señoríos; en 1422 los titulares de señoríos de baja jurisdicción enclavados en el realengo exigían al baile general la mitad de las herencias confiscadas a los

50. Archivo Histórico Nacional: Órdenes Militares, Montesa, carpeta 522, perg. 502-P (Onda, 1293). Otros ejemplos son los de Gestalgar, Benieto, Chiva y Godelleta, todos ellos del siglo XV (FEBRER, Manuel V.:

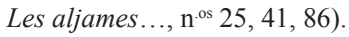

51. AO: fols. 103v-104r; Arxiu del Regne de València [ARV]: Reial Cancelleria [RC], reg. 630, fols. 217v-218r. Esta concesión se respetó en las capitulaciones otorgadas a las aljamas de Eslida, Castro y l'Alfondeguilla en 1365, tras perdonárseles su cooperación con las tropas del rey de Castilla (GUINOT, Enric: Cartes de poblament..., $\mathrm{n}^{\text {.os }} 273$ y 277 ).

52. ARV: RC, reg. 630, fol. 211rv (concesión de 1350); íd., fol. 213v (anulación de 1403), también en FV: E.49.1.

53. ARV: Maestre Racional [MR], 9.568, fol. 68r (duque de Gandia, 1403); ARV: RC, reg. 501, fol. 54r (señor de Geldo). 
musulmanes ${ }^{54}$. Por otra parte, los arrendadores podían negociar con los titulares de los señoríos cuyas rentas adquirían su participación en este importante derecho, que podía ir de un quinto a la mitad ${ }^{55}$.

El importe de la suma que, en concepto de «dret d'herències», se pagaba para eludir la confiscación resultaba muy variable, pero solía ser elevado, en la mayoría de los casos conocidos por encima de los 100 sueldos. Naturalmente el pago del rescate era opcional. Quienes mayor inclinación mostraban a realizarlo eran los viudos que pretendían retener el patrimonio de sus esposas fallecidas, básicamente, el acidach (ár. sidâq) o precio que ya habían pagado ellos mismos para dotarlas. De los cuatro ingresos que se registran en Cocentaina por «dret d'herències» en 1432, tres corresponden a pagos realizados por viudos para poder heredar bienes de sus esposas fallecidas; también son frecuentes este tipo de pagos en el condado de Dénia a fines del siglo XIV ${ }^{56}$. Gracias al sidâq, precisamente, los señores podían tener un conocimiento preciso de los bienes de las mujeres -sobre todo dinero y ropas- y obligar a los maridos a pagar derechos de herencia para recuperarlos si ellas morían sin descendientes vivos. Es muy significativo a este respecto que un bando publicado en 1492 por el señor de Sumacàrcer requiriese la formalización escrita del sidâq, autentificada además por la firma del alcaide, el baile y el procurador ${ }^{57}$. Podría decirse que las particularidades del régimen matrimonial musulmán hacían innecesario un control específico de los casamientos en un grado equiparable al de las formas europeas de servidumbre (formariage). Con la intervención sobre la herencia era suficiente.

Pero las limitaciones que pesaban sobre los derechos de los musulmanes en materia de enajenación y transmisión de bienes inmuebles no bastaban para asegurar en grado suficiente la permanencia de las unidades campesinas. Eran necesarios, sobre todo, impedimentos directos a la movilidad dotados de un adecuado respaldo legal. Y éstos apenas se hicieron esperar. Uno de los fueros nuevos otorgados por Jaime I en 1271 (o quizá en 1261) ya establecía que si algún musulmán abandonaba el lugar donde residía, el señor podía detenerlo y quitarle todos los bienes que llevase consigo, siempre que lo encontrase dentro del término del mismo lugar o castillo ${ }^{58}$. Resulta muy significativo que en el momento de seleccionar la rúbrica donde debía agregarse el nuevo fuero se escogiese la que llevaba por título De servis fugitivis, puesto que, en

54. En Benieto (1418) se establece que la mitad de los bienes del finado «seran del senyor major [i.e. el duque] e l'altra meytat serà del senyor del dit loch» (FEBRER, Manuel V.: Les aljames..., n. ${ }^{\circ}$ 41). Es el caso, también, de la alquería de Beniarjó, perteneciente a Ausiàs March: VILlaLmanzo, Jesús: Documenta Ausiàs March, Valencia: Institució Alfons el Magnànim, 1999, n. 326 (1450). La encuesta de 1422, en ARV: RC, reg. 630, fols. 214r-216r.

55. Febrer, Manuel V.: Les aljames..., n. ${ }^{\text {os }} 4$ (Llombai y Catadau, 1377), 82 (Picassent, 1467), 86 (Chiva y Godelleta, 1471), 101 (Paterna, 1483) y 103 (Benaguasil, 1483). Sólo en las dos últimas el arrendador se queda con el quinto, en el resto le corresponde la mitad.

56. ARV: MR, 9.839 , fol. 34v (Cocentaina, 1432): los tres ingresos suman 779 s. 6 d. Ejemplos de casos en el condado de Dénia: ARV: MR, 9.599, fols. 52v, 53v y 56v (1376); y 9.824-1, fols. 15r, 17v y 20r (1379).

57. PONS ALÓs, Vicent: El señorío de Sumacàrcer..., pp. 96-97.

58. FV: VI.1.24 
definitiva, se introducía las más decisiva de las restricciones serviles: el control de la movilidad residencial mediante el derecho de persecución, por limitado que fuese éste. Aunque el fuero no dice nada de los bienes inmuebles, parece claro que éstos revierten al señor sin ninguna compensación. Una cláusula de la carta de Gestalgar (1284) lo confirma: «si se va ningún moro a otro logar per morar allá, tot quanto éll lexa seent e movent es del senyor, pódelo dar o vendre ell senyor lo que lexa el moro». Con todo, un fuero y un acte de cort del siglo xv trataron de evitar cualquier ambigüedad en la interpretación: en el fuero (1446) se especificó que la confiscación afectaba tanto a los bienes muebles como inmuebles localizados «en lo terme o territori del senyor de qui tal moro o sarrahí era laurador o stadant»; en el acte de cort (1488), se precisaba que la pérdida de bienes se produciría aunque el musulmán no fuese detenido en el término de donde se marchaba o huía. De hecho, en un greuge de 1418 se interpretaba el fuero original como la capacidad señorial para apoderarse de todos los bienes muebles e inmuebles que el vasallo musulmán hubiese dejado en el término en caso de emigrar sin haber saldado antes sus deudas con el señor, lo que se denomina comptar ${ }^{59}$.

Es cierto que la deuda de los musulmanes emigrantes no se considera expresamente en el fuero de Jaime I, pero sí en un acte de cort del rey Martín del año 1403, donde se presta atención al perjuicio que representaba para los señores la pérdida de dichas deudas. Así, quienes acogiesen a los emigrados como nuevos vasallos quedaban obligados, bajo pena de $1.000 \mathrm{~s}$, a pagar las deudas de éstos con sus anteriores señores en el plazo de un mes; en caso contrario deberían entregarlos a los mismos para que los tuviesen en prisión hasta que saldasen toda la deuda y los gastos ocasionados ${ }^{60}$. Debe tenerse en cuenta que el endeudamiento de los campesinos musulmanes era, en buena medida, arbitrario y sin garantías. Cuando alguno de ellos se establecía en un lugar como vasallo, lo primero que se hacía era inscribirlo en un registro de deudas. Conocemos el de Alfafara de 1423-1428, donde se anotaron cuidadosamente las cantidades por las que quedaban obligados los campesinos, correspondientes no sólo a dinero y grano (trigo, cebada, espelta y avena), sino también a las armas que el señor les obligaba a comprar (ballestas, lanzas y paveses). Las sumas anotadas en moneda podían corresponder al precio de las tierras compradas por los inmigrantes, y no pocas veces se acumulaba, también, el importe de lo que debían a sus anteriores señores, que los nuevos habían accedido a pagar en su afán de procurarse vasallos ${ }^{61}$. El volumen de las deudas acumuladas por los miembros de una aljama podía alcanzar cifras muy considerables. Hacia fines del siglo XV la aljama de la Vall d'Alcalà, que no reuniría más de 70 u 80 familias, contaba 28.000 s. de «deutes antichs» con la señora del lugar, es decir, unos 350 o $400 \mathrm{~s}$. de endeudamiento familiar medio. Los préstamos realizados

59. PASTOR, Manuel: El cartulari..., n. ${ }^{\circ} 5$ (Gestalgar); FV: VI.1.26 (1446) y VI.1.28 (1488); ARV: RC, reg. 630, fol. 323r (1418): «com segur fur e enteniment d'aquell, quant lo moro se'n va d'algun loch sens comptar ab son senyor, que aquell li pot pendre tots los béns mobles que li trobe en son terme e los seents sien e romanen en domini e senyoria del dit senyor...».

60. FV: VI.1.25 (1403).

61. ARV: RC, reg. 675 , fols. $97 \mathrm{r}-105 \mathrm{v}$. 
por el doncel Jaume de Pertusa a siete campesinos musulmanes que poblaron su alquería de Xàtiva en 1429 ofrecen una magnitud similar, oscilando entre 240 s. y 378 s., con una media de $318 \mathrm{~s}^{62}$

Cualquier proyecto de emigración debía subordinarse al acto de liquidar la deuda, de comptar e comentar con el señor. Normalmente esto representaba una nueva ocasión para engrosar la deuda de modo artificial y atemperar la voluntad de emigrar. La carta de Ribesalbes (1405) pone de manifiesto la arbitrariedad de algunos de los conceptos que debían incluirse en la liquidación, ya que además de la deuda original y las rentas aún no pagadas, debían satisfacerse las remitidas por gracia durante los tres primeros años de residencia, así como el luismo de todos los bienes que se hubieran poseído mientras se habitó en el lugar, aunque ya no estuviesen en manos del interesado $^{63}$. Se trataba de un acto delicado, dadas las constantes discrepancias que surgían entre el señor y el vasallo emigrante, por lo que resultaba conveniente una formalización notarial ante testigos importantes, no exenta de cierta solemnidad ${ }^{64}$. Tal vez no resultaría exagerado sugerir que el acto de comptar resultaba equivalente, en cierto modo, a un rescate o redención.

La constitución de la deuda campesina representaba una traba importante a la emigración. Pero no era la única. El señor no siempre aceptaba la disposición a comptar manifestada por quienes deseaban marcharse, pudiendo reaccionar de modo violento ante la perspectiva de perder vasallos. Se entiende que esto era posible allí donde no tenía vigencia la obligación de vender antes la heredad a un sustituto. En 1429 el rey Alfonso escribió a diversos barones del reino haciéndose eco de una queja de los vecinos cristianos de Castellón, donde trataban de crear una morería. Según los prohombres de dicha villa, cuando los musulmanes que intentaban establecerse allí acudían a liquidar cuentas con los señores, eran detenidos y encerrados por éstos, impidiendo también que pudiesen llevarse bienes muebles o vender los inmuebles ${ }^{65}$. En los casos de migraciones en grupo el factor decisivo era, generalmente, la invitación realizada por otro señor o, cada vez más frecuentemente, por una villa deseosa de congre-

62. ARV: Justicia Civil, Manaments $i$ empares 1670, libro 3, mano 23-1 a fols. 39v-40r y 42r: testamento de Iolant Català de Valleriola (1496); el censo de 1510 cuenta 71 casas en el valle (VALLDECABRES, Rafael, ed.: El cens de $1510 \ldots$, p. 36), y el desarme de moriscos de 1563 registra hasta 78 casas (ARV: RC, reg. 564-II, fols. 625r-631v). Sobre la alquería de Pertusa, GARCíA MARSILlA, Juan V.: «Hábitat rural mudéjar y penetración del capital urbano en la huerta de Xàtiva a fines de la Edad Media», en VI Simposio Internacional de Mudejarismo, Teruel: Centro de Estudios Mudéjares, 1996, pp. 789-802, especialmente p. 796.

63. Guinot, Enric: Cartes de poblament..., n. ${ }^{\circ} 303$. El luismo, eso sí, es el foral del $10 \%$.

64. Un ejemplo en HinojosA, José: Los mudéjares..., II, n. ${ }^{\circ} 311$ (1480).

65. ARV: RC, 630:321rv: cum dicti sarraceni vobiscum seu cum officialibus vestris veniunt ad computandum et reddendum compotum et racione dire per eos vobis debitis iuxta formam fori, illos indebite et iniuste captos detinetis et vestris carceribus mancipatis, bonaque ipsorum mobilia a vestris dominiis seu locis abstrahere et secum asportare inhibetis, et sedencia vendere diversis coloribus, machinacionibus et ficcionibus prohibetis; etiam emparatis et sequestratis ac per vassallos vestros et alios emere nullatenus permititis in dicte universitatis et sarracenorum predictorum dampnum et periudicium manifestum... 
gar mano de obra barata en una morería adyacente, ofreciendo algunas ventajas en el establecimiento. Durante el siglo XV tales instigaciones y los movimientos generados por las mismas alcanzaron cierta intensidad, de modo que los señores de campesinos musulmanes trataron por todos los medios de bloquear las migraciones. En las cortes de 1446, el heredero de la corona, Juan de Navarra, considerando los «scomoviments o anades que alguns moros fan partint-se instadament de les poblacions on habiten», accedió a promulgar un nuevo fuero según el cual se precisaba una licencia expresa del señor para que cuatro o más «casats de moros» pudiesen abandonar simultáneamente («ajustats ensemps») un determinado lugar. Este fuero consagraba, al parecer, una práctica ya existente que se advierte en la actuación del señor de Sumacàrcer en 1417, cuando declaraba que la costumbre admitida era que los vasallos musulmanes emigrasen individualmente y «per discurs del temps», no en grupo y a la vez. La estrategia adoptada por éstos consistió, ante todo, en abandonar sus residencias por separado, aunque fuesen al mismo lugar. Esto no impidió que en 1459 el señor de Borriol capturase antiguos vasallos suyos instalados en la morería de Castellón y los hiciese encerrar en los castillos de Artana y Borriol, pese a haberse marchado tras presentar al señor su nuevo avecindamiento, de día y públicamente ${ }^{66}$. Por lo demás, el fuero de 1446 liquidó de forma definitiva la posibilidad de que las aljamas ejerciesen legalmente la advertencia de abandono colectivo como defensa ante los abusos.

En caso de huida declarada, la eficacia del derecho de persecución contra los campesinos musulmanes se veía garantizada por la existencia, desde 1298, de una jurisdicción supralocal en manos de los dos oficiales mayores del reino, el baile general y el procurador general o gobernador (aunque éste sólo para los musulmanes de la nobleza $)^{67}$. Las huidas no sólo se debían al maltrato señorial o a la imposibilidad de redimir castigos corporales. De lo que se trataba, en la mayoría de los casos, era de escapar de una situación que bloqueaba cualquier posibilidad de ahorro o mejora de las condiciones de vida. En otras palabras, zafarse de la deuda. Los primeros testimonios claros del derecho de persecución proceden de una fecha tan significativa como es el año 1284, cuando el rey Pedro reconoce haber concedido a los prohombres de Xàtiva capacidad para capturar a los enfiteutas musulmanes que abandonasen las heredades con deudas pendientes, pidiendo al mismo tiempo la colaboración del justicia. El derecho de persecución, ejercido además sin garantías legales para los perseguidos, deforma por completo el aparente carácter contractual de la relación entre campesinos y terratenientes o señores, dado que los primeros quedan expuestos a la prisión, el castigo corporal y la esclavitud ${ }^{68}$. Las nociones jurídicas de enfiteusis o aparcería, tomadas de forma aislada, no pueden dar cuenta, adecuadamente, de la naturaleza de dicha relación.

66. FV: VI.1.27 (1446); GuINOT, Enric: Cartes de poblament..., n. ${ }^{\circ} 307$ (Sumacàrcer, 1417); HinOJOSA, José: Los mudéjares..., II, n. ${ }^{\circ} 155$ (Borriol, 1459).

67. $A O:$ fol. $40 \mathrm{v}$.

68. ACA: RC, reg. 46, fol. 168r (Xàtiva). He estudiado más casos en ToRRó, Josep: «Exàrics et exameces...». 
Las huidas y ocultaciones que se producen en Elx cuando acuden los recaudadores de las rentas motivan que Jaime II ordene, en 1321, el castigo de los fugitivos con veinte azotes, y prisión para quienes, además, deben dinero, manteniéndolos así hasta saldar la deuda ${ }^{69}$. Tal situación deriva fácilmente en cautiverio, ya que acceder a ser vendido como esclavo, con la esperanza de rescatarse posteriormente, es muchas veces el único modo de sortear la prisión ${ }^{70}$. Este tipo de práctica debió tener cierta incidencia. Parece que hacia 1402 algunos campesinos de las aljamas del duque de Gandia tenían la costumbre de ofrecer sus propios hijos e hijas como garantía de los préstamos que contrataban con cristianos o judíos, de modo que la insolvencia paterna podía llegar a convertirlos en cautivos a perpetuidad. Así, el endeudamiento constituía, de hecho, una de las principales causas de cautiverio, junto a otras muchas, como transitar por sendas en lugar de hacerlo por caminos mayores, regar de noche, cazar en algunos lugares o coger leña y esparto fuera del distrito de residencia, tal y como sucedía en la gobernación de Orihuela ${ }^{71}$.

Otra cosa era la emigración exterior de los musulmanes, aunque en ocasiones fue valorada por oficiales del rey como una reacción a las dificultades que se interponían a las migraciones interiores, al «mudar de un loch a altre $»^{72}$. La relativa frecuencia con que dicha partida adoptaba la forma de huida debería relacionarse con la intención de evitar las cargas que la gravaban o, sencillamente, las prohibiciones absolutas que los reyes ponían oportunamente en vigor, cuando consideraban que las circunstancias podían propiciar emigraciones masivas, y que terminaron por hacerse definitivas en el siglo XV. La tasa original impuesta a los musulmanes que salían del reino consistía en una décima parte de todos los objetos y monedas transportados, castigándose el impago con la confiscación de bienes y personas, según la práctica que el baile general ya consideraba ordinaria en 1320. Este derecho correspondía exclusivamente al rey como señor de las fronteras del reino, aunque algunos nobles intentaron con poco éxito

69. FERRER, Ma Teresa: Les aljames sarraïnes de la governació d'Oriola en el segle XIV, Barcelona: CSIC, 1988, doc. 66; como consecuencia probable de tales hechos, el rey ordena poco después al baile que restituya a los viejos de la aljama la responsabilidad de asignar las contribuciones a la alfarda, dado que se hacía mejor cuando se encargaban ellos y no el recaudador real (ibíd., doc. 67).

70. Boswell, John: The Royal Treasure. Muslim Communities under the Crown of Aragon in the Fourteenth Century, New Haven-London:Yale University Press, 1977, pp. 332-334.

71. ARV: MR, 9.568, fols. 21v-22r: «siam plenerament informats que molts serrahins dels lochs e aljames nostres de la dita nostra terra, en manifest e notori perjuhí de nostres drets e de lurs fils, temeràriament han ensajat e de fet han fets manleutes e barates e altres contractes, axí ab cristians com juheus e d'altres, en los quals empenyoren e obliguen llurs fills e filles, de què·s seguex a vegades captivitat perpetual de aquells, ço que fer no poden en perjuhí de nostres drets e dels dits fills o filles lurs e contra llur çuna e xara e disposició e raó natural»; el duque prohíbe esta práctica bajo pena de 200 azotes y la nulidad de los contratos. Los motivos de cautiverio para la gobernación de Orihuela se establecen en una ordenación de 1315 (FEBRER, Manuel V.: Cartas pueblas..., n. ${ }^{\circ} 135$ ).

72. ARV: RC, reg. 111, fols. 15v-17v (1474): «car essent fet opòsit als moros del dit regne en lo mudar de un loch a altre és estat vist passar-se'n en Granada o en Castella, ço que redunda en gran dan e desservey nostre e evident perjudici del dit regne...». 
apoderarse de la recaudación del mismo en sus distritos ${ }^{73}$. En 1322, sin embargo, estaba vigente una prohibición que impedía a los musulmanes abandonar el reino, aunque pagasen, y que se levantó precisamente entonces, en virtud de una cláusula de la paz firmada entre Jaime II y el sultán de Granada. De nuevo, en 1361, el rey Pedro tuvo que otorgar al granadino un levantamiento del veto a la emigración de Valencia, pero corrió el rumor de que la salida podía ser tan numerosa que el monarca trató de minimizar sus efectos con todos los medios a su alcance. Así, ordenó que el viaje no se efectuase por tierra para evitar, decía, que los hombres de su enemigo, el rey de Castilla, interrogasen a los musulmanes y que éste se alegrase de verlos salir; se encargó a un dignatario musulmán de confianza que mediase para que «dels dits moros no isquen a adés sinó com menys puguen»; y, en general, se dispuso un discreto sabotaje de los preparativos de partida para que no lo advirtiese el enviado del sultán ${ }^{74}$.

La guerra con Castilla y sus repercusiones inmediatas provocaron, indudablemente, un aumento de la propensión migratoria de los musulmanes hacia Granada y el Magreb que, unido a la pérdida general de población generada por las calamidades bélicas y epidémicas, desató la alarma de los estamentos del reino. Las restricciones a la emigración habían aumentado: sólo se podía salir con licencia expresa del rey, y pagando una quinta parte de los bienes en lugar de la décima habitual. Aun así, en las cortes de Sant Mateu de 1370 los tres brazos protestaron por los perjuicios que les causaba la autorización real, señalando que el reino se habría quedado sin moros si el hijo y procurador del monarca no la hubiese suspendido. Argumentando que la emigración de los musulmanes les dejaría sin rentas y, por tanto, sin capacidad de aportar subsidios a la corona, los estamentos pidieron la suspensión perpetua de las licencias, pero el rey sólo la admitió durante diez años ${ }^{75}$. Debe tenerse en cuenta que en el momento de celebrarse las mencionadas cortes de 1370 la situación había dado un vuelco respecto a la de las cuatro primeras décadas del siglo XIV, cuando la población cristiana del reino se hallaba en crecimiento. En aquellos momentos las amenazas de una expulsión general parecían confirmarse a través de episodios locales de extrañamiento y parecía factible

73. FeBrer, Manuel V.: Cartas pueblas..., $\mathrm{n}^{\text {os }} 140$ (1320) y 149 (1325).

74. FERRER, Manuel V.: Les aljames sarraïnes..., doc. 75 (1322): fuit conditum quod nos infra tempus dicte pacis non prohibemus alicui sarraceno terre nostre qui ad sarracenorum partes, si vellet, posset accedere, iura assueta solvendo...; HINOJOSA, José: Los mudéjares..., II, n. ${ }^{\circ} 137$ (1361): «volem que quant a aquells que per mar se·n volen anar, que tingats aquelles maneres que porets que no·n isquen sinó com menys puguen, e que $y$ façats tot aquell restrenyement que pugats, però secretament $\mathrm{e} a b$ bones maneres, de guisa que 1 missager del rey de Granada no conega ni senta que en res li vingam a menys del atorgament per nós a ell fet, axí com no·u entenem a fer; ans volem que·us monstrets fort liberals en lo dit eximent, però lo fet e la obra sia altra».

75. FV: VI.1.30: «car si los dits moros se·n van, los dits prelats, cavallers e persones generoses e hòmens de ciutats e viles no hauran ne poran haver de què viuen ne puxen servir a vós, senyor, en vostres necessitats». Hubo, con todo, alguna excepción: en 1372 un miembro acomodado de la aljama de Eslida emigró al Magreb con su familia - cinco personas- tras pagar el diezmo de sus bienes muebles, el besante (4 s. por cabeza) y un derecho nuevo, llamado de la media dobla ( $8 \mathrm{~s}$. por cabeza), en total $227 \mathrm{~s}$. y medio (Hinojosa, José: Los mudéjares..., II, n. ${ }^{\circ}$ 141). 
completar el proceso de sustitución poblacional iniciado con la conquista. Ahora, en cambio, los campesinos musulmanes eran objeto de demanda y todos reclamaban que se estrechasen los controles sobre su movilidad. Había que mantenerlos dentro del reino.

Las puertas de salida se cerraron definitivamente en 1403, al menos en términos legales. Un fuero del rey Martín, confirmado cinco años después, prohibió de modo taxativo la emigración de los musulmanes del reino, aunque tuviesen licencia, aunque hubiesen pagado el diezmo o el quinto, bajo la pena habitual de cautiverio y confiscación de bienes. El baile general continuó dando licencias furtivamente, dado que las tasas aplicadas a los emigrantes representaban una fuente de ingresos rápidos y apreciables, pero el contrafuero motivó que el brazo militar elevase una protesta al rey Alfonso en las cortes de $1418^{76}$. Una orden de Juan II (1476) reincidía en la prohibición, dada la frecuencia de los intentos de huida, a veces con licencias de los bailes reales; también lo hizo un nuevo fuero de Fernando II (1488), según el cual sólo se podían permitir las salidas relacionadas con actividades de trajinería en Aragón, Cataluña y Castilla ${ }^{77}$.

En síntesis, cuando en 1528 los representantes ante el emperador de las aljamas valencianas alegaban hallarse «forçados d'estar en los lugares» no se referían literalmente a una adscripción personal a la tierra, ni a una impensable ausencia total de traslados, sino a mecanismos mucho más complejos, y a su modo sin duda eficaces, de administración de la movilidad geográfica. Ésta podía ser, de hecho, bastante intensa, pero discurría a través de unos cauces prácticamente infranqueables y con una espontaneidad mucho menor de lo que podría parecer a primera vista. Ante todo, la migración interior sólo podía dirigirse hacia otras aljamas o morerías constituidas, puesto que, como sabemos, la distribución espacial de la población musulmana en el reino estaba determinada por una estricta segregación residencial. A esta limitación se añadían los poderosos recursos de que disponían los señores para regular a conveniencia la salida de vasallos musulmanes de sus tierras, basados sobre todo en el control de enajenaciones y transmisiones, la manipulación de la deuda campesina y la facultad coercitiva que se derivaba del derecho de persecución. Finalmente, no podemos olvidar la autoridad que el rey ejercía sobre las fronteras, dosificando a conveniencia la emigración exterior y, finalmente, impidiéndola mediante disposiciones legales expresas. Todo ello con el sólido respaldo que otorgaba la capacidad de reducir a cautiverio a quienes protagonizasen cualquier tipo de transgresión al realizar sus desplazamientos ${ }^{78}$.

76. FV: VI.1.31 (1403), VI.1.32 (1408), VI.1.33 (1418).

77. ARV: Batlia General, 1.155, fols. 698v-699r (1476): sarraceni dicti regni... non audiant sub pena servitutis et confiscatione curie nostre bonorum suorum, transire ad dictas partes maurorum cum licentia aut sine licentia baiulorum aut alicuius officialis nostris, nisi nos eam concedentes (es decir, el rey se reservaba el derecho personal de otorgar alguna licencia); FV: VI.1. 34 (1488).

78. Sobre el cautiverio como instrumento de control de la población musulmana, vid. TorRó, Josep: «'De bona guerra'. El ambiguo estatuto del cautivo musulmán en los países de la Corona de Aragón (siglos XII-XIII)», en FIERRO, M., y GARCÍA FITZ, F. (eds.): El cuerpo derrotado: Cómo trataban musulmanes y cristianos a los enemigos vencidos (Península Ibérica, ss. VIII-XIII), Madrid: CSIC, 2008, pp. 435-483. 


\section{OBSERVACIONES FINALES: SERVIDUMBRE Y ASIMILACIÓN}

Aun tratándose de una exposición bastante sintética, creo haber mostrado suficientemente que los agravios presentados por los doce síndicos de las aljamas al emperador Carlos contaban con un gran fondo de evidencia, además de una larga genealogía que se remontaba a la época inmediatamente posterior a la conquista y que nos obliga, en cualquier caso, a situar la cuestión morisca en la problemática, más amplia, de las condiciones de permanencia de la población musulmana del reino valenciano ${ }^{79}$. Una permanencia subordinada al control de la movilidad geográfica (bien limitándola, bien sometiéndola a requisitos que la hicieran aceptable para los señores) y que las prohibiciones a la migración exterior convertirían en un confinamiento general en el interior del reino, haciendo de la huida la única opción para quienes deseasen abandonarlo, especialmente a partir del siglo $\mathrm{XV}^{80}$. La retención territorial de los musulmanes era, a fin de cuentas, la condición necesaria para el ejercicio de las formas específicas de explotación mediante rentas y servicios que se aplicaron a los mismos, notablemente más intensas que las soportadas por el campesinado cristiano y, por eso mismo, claramente envilecedoras; se dotaba, así, de un obvio contenido de estatus a la simple diferenciación étnico-religiosa. La única definición posible de este sistema basado en la «sujeción legal» no es otra que la de servidumbre ${ }^{81}$.

Ciertamente no se trata de una servidumbre «clásica», individual o familiar, definida por vínculos personales de sujeción a un señor o a una tenencia en concreto, sino de un sistema coherente de restricciones legales, respaldadas por dispositivos de coacción muy poderosos dirigidos al control de la unidad familiar, sí, pero también y por encima de todo, al conjunto de la población musulmana del reino, el cuerpo social o «nación» sometida. Se trataría pues, de una fijación general, a escala del reino (y, dentro de éste, a las zonas reservadas al efecto), compartida y disputada por los grupos privilegiados en condiciones de ejercer el dominio señorial sobre fracciones de dicha población (el rey, aristócratas laicos, instituciones eclesiásticas, ciudadanos poseedores de señoríos). Este sistema puede denominarse servidumbre colectiva porque es un marcador colectivo expresado en lenguaje eclesiástico -la infidelidad de los musulma-

79. Evito el término «mudéjar» porque realmente no introduce ninguna precisión de orden conceptual y constituye una singularidad «hispánica» inadecuada respecto a otras experiencias paralelas de dominio cristiano-latino sobre poblaciones musulmanas.

80. En otro lugar he comparado esta situación con la del campesinado griego en los dominios venecianos del Egeo y, particularmente, en Creta. No se trata, pues, de ninguna excepcionalidad, sino de mecanismos de dominación de sociedades «exteriores» practicados en circunstancias análogas: TORRÓ, Josep: «Colonizaciones y colonialismo medievales. La experiencia catalano-aragonesa y su contexto», en Cano, G., y Delgado, A. (eds.): De Tartessos a Manila. Siete estudios coloniales y poscoloniales, Valencia: PUV, 2008, pp. 91-118.

81. Vid. BusH, Michael L.: «Serfdom in medieval and modern Europe: a comparison», en ibíd. (ed.): Serfdom \& Slavery. Studies in Legal Bondage, Londres-Nueva York: Longman, 1996, pp. 199-224; FreEdman, Paul, y Bourin, Monique: «Introduction», en ibíd. (eds.): Forms of servitude in Northern and Central Europe: decline, resistance and expansion, Turnhout: Brepols, 2005, pp. 1-16. 
nes- lo que permite perfilar con absoluta precisión el cuerpo social destinatario de las prácticas serviles $^{82}$.

La segregación matrimonial y residencial era, en consecuencia, una pieza absolutamente fundamental de este sistema servil. Servidumbre y segregación se reforzaban mutuamente y bloqueaban las posibilidades de asimilación. Ésta, en la medida que podía difuminar los contornos del conjunto de población sujeto a dicho sistema, no interesaba de ningún modo a los señores que dependían de las rentas obtenidas de musulmanes para sostener su nivel de vida y de endeudamiento. La conversión general de los musulmanes del reino de Valencia en «cristianos nuevos», declarada en 1526, debe considerarse necesariamente desde esta perspectiva. Y es que, como sabemos muy bien, esta conversión no modificó -al menos en sentido favorable a los forzados conversos- las condiciones en materia de rentas, servicios y movilidad.

Sin duda, nos hallamos ante una cuestión central en los debates actuales sobre el problema morisco. Situar de forma equilibrada los argumentos expuestos anteriormente en el contexto de esta discusión historiográfica rebasaría con mucho el objetivo del presente artículo, por lo que no voy a extenderme al respecto ${ }^{83}$. Sí que me gustaría, no obstante, rápidamente y evitando cualquier alusión concreta, efectuar un par de observaciones a propósito de los conceptos de servidumbre y segregación que, a veces, son manejados en estos debates de forma un tanto un confusa. La primera consiste en recordar que la servidumbre es una condición de estatus personal (o colectivo) que tiende a la fijación espacial de las unidades familiares; no tiene que ver, pues, con el «nivel de vida» o la riqueza eventualmente reunida, por lo que -excepcionalmente, eso sí- pueden darse casos de familias relativamente acomodadas. Es del todo falaz, asimismo, la frecuente ecuación entre servidumbre y «pasividad», que remite a una supuesta sumisión incondicional. Se trata, además de una equivalencia equívoca, porque si se dice que los musulmanes (o moriscos) «no eran siervos pasivos» se entiende, o puede entenderse, que no estaban sujetos a servidumbre. Creo que la descripción de los mecanismos de control sucesivamente adoptados por los señores de campesinos musulmanes deja ver claramente la capacidad de resistencia de las aljamas y todo el abanico de acciones desarrolladas por éstas o por sus miembros individuales para soslayar los constreñimientos establecidos y aprovechar cualquier oportunidad de mejora. En pos de restituir un legítimo protagonismo a los dominados, el discurso «poscolonial» acaba por olvidar la dominación, siendo así que el sentido, el alcance,

82. He expuesto esta tesis en un trabajo aún inédito, cuyos argumentos esenciales sigo aquí: Josep ToRRÓ, Josep: “'Nación de siervos'. Los campesinos musulmanes del reino de Valencia. ¿Una servidumbre colectiva?», Revista d'Història Medieval, Valencia, 2003-2004, 13, en prensa. Recientemente he advertido que la expresión «servage collectif» ya fue aplicada hace cuarenta años, aunque sin razonamiento previo, al estatuto de la población morisca valenciana por PARAIN, Charles: «Évolution du système féodal européen», en Sur le féodalisme, París: Editions Sociales, 1971, pp. 18-48, especialmente p. 31.

83. Remito a la reciente y ponderada síntesis de las posiciones historiográficas elaborada por PARDO Molero, Juan F.: «Los moriscos valencianos. Vigencia de un tópico historiográfico», Revista d'Història Medieval, Valencia, 2001-2002, 12, pp. 155-184. 
las estrategias y los márgenes de actuación, las líneas a transgredir, vienen marcadas justamente por las condiciones concretas de dominio. Es un problema de jerarquía de conocimientos.

El segundo comentario se refiere al concepto de segregación. La existencia de una segregación de orden jurídico, residencial y sexual respaldada en normas legales muy precisas es absolutamente incontestable. Y no tiene nada que ver con el ámbito de las «relaciones personales» $\mathrm{o}$, incluso con la posibilidad manifiesta de transgresiones excepcionales, como las que representaban los contactos sexuales furtivos. Lo que no había, de ningún modo, eran posibilidades de alianzas «mixtas», es decir, de imbricación en las relaciones (matrimoniales y familiares) que ordenaban socialmente la reproducción biológica en el seno de cada grupo, musulmán y cristiano. Ni siquiera después de la conversión formal de 1526. He definido esta forma de coexistencia entre dos cuerpos sociales como reproducción separada ${ }^{84}$. No puede negarse que la conversión representaba un desafío a la reproducción separada, pero tampoco que se mostraría del todo insuficiente para romper el bloqueo servil al establecimiento de relaciones en plano de igualdad entre miembros de ambas comunidades.

En la práctica no podía haber asimilación, ya que se mantenía una clara diferenciación de estatus que hacía imposible o muy difícil el paso previo de una necesaria imbricación residencial y matrimonial entre cristianos viejos y «nuevos». De hecho, muchos eclesiásticos estaban convencidos de que la permanencia del estatus servil de la población morisca, a la que equiparaban explícitamente con «esclavos» y «negros» de los señores, constituía el principal obstáculo a su cristianización efectiva. Señalaban, además, por donde debía pasar una eventual solución: relevarles de «malas imposiciones», no hacerles pagar «más que si fuesen cristianos», liberarlos «de estos pechos», concederles «inmunidad de cristianos viejos». No lo pretendían, sin duda, de un modo inmediato e incondicional, pero reconocían con claridad la esencia del problema ${ }^{85}$.

Cuando el doctor Frago, en la junta de 1561, señaló la incongruencia que representaba para los nuevos convertidos «vivir como cristianos y pagar como moros» enunciaba, de hecho, el fundamento de una conversión sin asimilación: poner bajo el control de la Iglesia un cuerpo social sometido por derecho de conquista y segregado a efectos de su explotación servil, con todas las tensiones que, inevitablemente, generaba dicha situación. Es importante advertir que esto no representaba una novedad. En el muy comentado discurso que, a propósito de los medios más adecuados para la conversión real de los moriscos del reino valenciano, hizo José Estevan, obispo de Orihuela, en 1595, tuvo la sagacidad de comparar la situación de éstos con la de los indios en encomienda (citando a Bartolomé de las Casas) o, incluso, con la de los paganos lapones

84. TORRó, Josep: El naixement..., pp. 21 y 233; ibíd.: «Jérusalem ou Valence. La première colonie d'Occident», Annales HSC, París, 2000, 55:5, pp. 983-1.008, especialmente p. 1.007.

85. BoronAt, Pascual: Los moriscos..., I, pp. 603-607 (1582), 629 (1587), y II, pp. 701-703 (1608): calificación de los moriscos como esclavos efectuada por el patriarca Ribera, el obispo de Segorbe (Martín de Salvatierra) y el franciscano Antonio Sobrino; ibíd., I, pp. 531-532 (1561), 642-643 (1596), 650-651 (1596), y II, p. 703 (1608): eliminación de cargas. 
del norte de Suecia cuya incipiente cristianización saboteaban sus señores «por miedo de perder sus tributos y rentas» (según un informe portugués redactado hacia 1530) ${ }^{86}$.

No debe perderse de vista, en fin, que el control eclesiástico iba mucho más allá de la supresión de ritos, indumentaria y lengua. Perseguía directamente a los alfaquíes, el último resto del aparato jurídico-religioso y educativo islámico, el grupo social que garantizaba la cohesión y la continuidad de las comunidades musulmanas. E implicaba, sobre todo, un cambio decisivo en el régimen matrimonial y de herencia de los musulmanes que, sin duda, tendría efectos disolventes sobre las redes de parentesco y los mismos grupos domésticos, lo que también podía afectar a la organización específica de sus prácticas agrarias. Aunque estas cuestiones aún no han sido estudiadas debidamente, parece razonable afirmar que la imposición de las normas eclesiásticas minaba los fundamentos materiales de la reproducción del cuerpo social morisco, debilitando así su capacidad para soportar las cargas rentísticas y serviles de que eran objeto: grupos familiares extensos, división doméstica del trabajo, gestión indivisa de animales de establo y corral, organización de actividades comunitarias por turnos, etc. Resulta comprensible, así, que la Iglesia se inclinase a mitigar o suprimir dichas cargas; como también la resistencia de los moriscos a una conversión que no sólo no los igualaba socialmente con los cristianos viejos, sino que amenazaba con destruir las mismas bases de su existencia.

86. Ibíd., I, pp. 531 (Frago), 643 y 650 (Estevan). Sobre la comparación de las conversiones de indios y moriscos, BARCELÓ, Miquel: «Bartolomé de las Casas, moriscos i catalans. Dues notes historiogràfiques», Afers, Catarroja, 2007, 56, pp. 113-130. 